\title{
Spatial variation of chemical composition and sources of submicron aerosol in Zurich during wintertime using mobile aerosol mass spectrometer data
}

\author{
C. Mohr ${ }^{1}$, R. Richter ${ }^{1}$, P. F. DeCarlo ${ }^{1, *}$, A. S. H. Prévôt ${ }^{1}$, and U. Baltensperger ${ }^{1}$ \\ ${ }^{1}$ Laboratory of Atmospheric Chemistry, Paul Scherrer Institut (PSI), Villigen, Switzerland \\ * now at: AAAS Science and Technology Policy Fellow hosted at the US EPA, Washington 7 DC, USA
}

Received: 7 March 2011 - Published in Atmos. Chem. Phys. Discuss.: 19 April 2011

Revised: 18 July 2011 - Accepted: 19 July 2011 - Published: 1 August 2011

\begin{abstract}
Mobile measurements of $\mathrm{PM}_{1}$ (particulate matter with an aerodynamic diameter $<1 \mu \mathrm{m}$ ) chemical composition using a quadrupole aerosol mass spectrometer and a multi-angle absorption photometer were performed using the PSI mobile laboratory during winter 2007/2008 and December 2008 in the metropolitan area of Zurich, Switzerland. Positive matrix factorization (PMF) applied to the organic fraction of $\mathrm{PM}_{1}$ yielded 3 factors: Hydrocarbon-like organic aerosol (HOA) related to traffic emissions; organic aerosol from wood burning for domestic heating purposes (WBOA); and oxygenated organic aerosol (OOA), assigned to secondary organic aerosol formed by oxidation of volatile precursors. The chemical composition of $\mathrm{PM}_{1}$ was assessed for an urban background site and various sites throughout the city. The background site is dominated by secondary inorganic and organic species $(57 \%), \mathrm{BC}, \mathrm{HOA}$, and WBOA account for $15 \%, 6 \%$, and $12 \%$, respectively. As for the other sites, HOA is important along major roads (varying between 7 and $14 \%$ of $\mathrm{PM}_{1}$ for different sites within the city, average all sites $8 \%$ ), domestic wood burning makes up between $8-15 \%$ of $\mathrm{PM}_{1}$ for different sites within the city (average all sites $10.5 \%$ ). OOA makes up the largest fraction of organic aerosol (44\% on average). A new method allows for the separation and quantification of the local fraction of $\mathrm{PM}_{1}$ emitted or rapidly formed in the city, and the fraction of $\mathrm{PM}_{1}$ originating from the urban background. The method is based on simultaneous on-road mobile and stationary background measurements and the correction of small-scale meteorological effects using the ratio of on-road sulfate to stationary sulfate. Especially during thermal inversions over the Swiss plateau, urban background concentrations contribute
\end{abstract}

Correspondence to: A. S. H. Prévôt (andre.prevot@psi.ch) substantially to particulate number concentrations (between 40 and $80 \%$ depending on meteorological conditions and emissions, $60 \%$ on average) as well as to the mass concentrations of $\mathrm{PM}_{1}$ components measured on road in downtown Zurich (between 30 and $90 \%$, on average $60 \%$ for black carbon and HOA, and between 90 and $100 \%$ for WBOA, OOA, and the measured inorganic components). The results emphasize, on a scientific level, the advantage of mobile measurements for distinguishing local from regional air pollution research, and on a political level, the importance of regional collaboration for mitigating air pollution issues.

\section{Introduction}

Atmospheric aerosols, liquid or solid particles suspended in the air, influence our climate (IPCC, 2007), affect regional visibility (Watson, 2002), and impair human health (Pope and Dockery, 2006). These effects make them the focal point of numerous research activities. Laboratory experiments (e.g. "smog chamber studies") and field measurement campaigns all over the world have led to vast advances in the understanding of their sources, their physical and chemical properties, and their evolution in the atmosphere. However, aerosol particles are still less understood than gas phase species due to their heterogeneous distribution, short atmospheric lifetimes compared to longer-lived gases, and the analytical challenges faced when investigating small particles (Posfai and Buseck, 2010). This is especially true for the organic fraction of particulate matter (PM), typically making up 20-90\% of the submicron aerosol mass (Jimenez et al., 2009).

Published by Copernicus Publications on behalf of the European Geosciences Union. 
Health effects of PM are especially important in highly populated areas. A growing portion of the world's population lives in cities and megacities, being exposed to an increased risk of morbidity and pre-mature mortality due to poor air quality (Baldasano et al., 2003; Molina and Molina, 2004; Gurjar et al., 2010). Therefore, field campaigns in urban centers (e.g., Milan, Italy, Mexico City, Mexico, Barcelona, Spain), addressing emissions from urban anthropogenic activities as well as the evolution of the city's pollution plume to surrounding areas, are an important and widely applied part of aerosol research (e.g. Baltensperger et al., 2002; Zhang et al., 2004; Molina et al., 2010; Pandolfi et al., 2011). The city of Zurich, Switzerland, with $\sim 400000$ inhabitants, has been the focus of previous field studies, e.g. investigations on the contribution of road traffic to ambient levels of fine particles (Gehrig et al., 2001), non-exhaust particles generated by road traffic (Bukowiecki et al., 2010), the chemical composition of PM (Hueglin et al., 2005), sources of organic aerosol by means of factor analytical modeling of mass spectrometer data (Lanz et al., 2007), or the fossil and non-fossil fraction of carbonaceous aerosol (Szidat et al., 2006). Especially high PM concentrations (up to $120 \mu \mathrm{g} \mathrm{m}^{-3}$ ) can be observed during winter time due to thermal inversions preventing dilution of emissions, and increased emissions from wood burning for domestic heating purposes (Lanz et al., 2008).

The multitude and complexity of processes leading to high aerosol mass and number concentrations on a local or regional scale have made it difficult for policy makers to successfully design and implement mitigation activities for PM, in which knowledge about sources is a prerequisite. This in turn requires information on particulate chemical composition. Developments in the field of aerosol mass spectrometry during the last decade have made real-time online measurements of the chemical composition of PM possible (Canagaratna et al., 2007; Baltensperger et al., 2010). In 2005, a new technique involving a series of multivariate linear regressions was published (Zhang et al., 2005), allowing for deconvolution of the organic mass spectral data matrix measured by a quadrupole aerosol mass spectrometer (Q-AMS) into a chemically reduced fraction called hydrocarbon-like organic aerosol (HOA), assigned to primary emissions, and an oxygenated organic aerosol (OOA) fraction, related to secondary formation of PM from volatile organic precursors. Lanz et al. (2007) combined Q-AMS organic mass spectral data with the factor analytical model positive matrix factorization (Paatero and Tapper, 1993, 1994), and were able to further separate organic source components, including a subdivision of OOA into a low-volatility (OOA I) and a semivolatile (OOA II) fraction.

Infrastructure requirements of aerosol and gas-phase instrumentation put restrictions on ambient air quality measurements, which often lead to a fixed installation of instruments at a designated place with sufficient power and protection. However, in addition to temporal evolution, the spatial variation of the parameters of interest can be of importance for explaining particular atmospheric processes. Previous studies either featured the same type of instruments at various sites simultaneously (e.g. Mejia et al., 2008; Xie et al., 2008), or a set of various instruments mounted on a mobile platform. Many mobile measurements have been performed using aircraft (e.g. Schneider et al., 2006; Bahreini et al., 2003; DeCarlo et al., 2008), or, if ground-based, focused on vehicle exhaust (e.g. Canagaratna et al., 2004; Zavala et al., 2009; Thornhill et al., 2010). Only few studies covered groundbased spatially resolved particle characterization or source apportionment (Bukowiecki et al., 2002, 2003; Weimer et al., 2009).

The present study combines ground-based mobile AMS measurements with PMF source apportionment. It was our goal to explore the spatial variation of the chemical composition of $\mathrm{PM}_{1}$ (particulate matter with an aerodynamic diameter $D<1 \mu \mathrm{m}$ ) for winter time in the city of Zurich. A new method to distinguish the local fraction of $\mathrm{PM}_{1}$ from the fraction related to the urban background will be presented. This differentiation is of high importance for local policy makers concerned with air quality.

\section{Methods}

\subsection{Zurich mobile measurement campaigns}

For 10 days between 27 November 2007 and 16 December 2008 on-road mobile measurements were performed in the city of Zurich, Switzerland ( $400 \mathrm{~m}$ a.s.l.), representing 66 hours of data. Measurements of the $\mathrm{PM}_{1}$ chemical composition, size distribution and number concentration, trace gas concentrations $\left(\mathrm{NO}_{\mathrm{x}}, \mathrm{CO}, \mathrm{CO}_{2}\right)$, and meteorological and geographical parameters (temperature, relative humidity, solar radiation, altitude, longitude, latitude) were conducted. Figure 1 gives an overview of the dates and times of measurement and the number of loops driven along the chosen route. The route was chosen such that major traffic arteries, residential areas, suburbs, and surrounding hills were covered. After each loop, stationary data were acquired at the urban background site "Kaserne" for a few minutes. Zurich Kaserne has been characterized in previous studies as "urban background" for $\mathrm{PM}_{10}, \mathrm{PM}_{2.5}$, and $\mathrm{PM}_{1}$ and additional air quality parameters (Gehrig and Buchmann, 2003; Hueglin et al., 2005; Szidat et al., 2006; Bukowiecki et al., 2010; Lanz et al., 2008). It is a courtyard shielded from direct emissions by its surrounding walls. In addition, the roads in its vicinity belong to residential areas with only minor traffic density. The site is part of the Swiss National Air Pollution Monitoring Network (NABEL).

Mobile measurements were usually performed during morning and evening periods, when traffic and domestic heating emissions are at their maximum (Lanz et al., 2008; Krecl et al., 2008), for about 3-4h each, and normally 


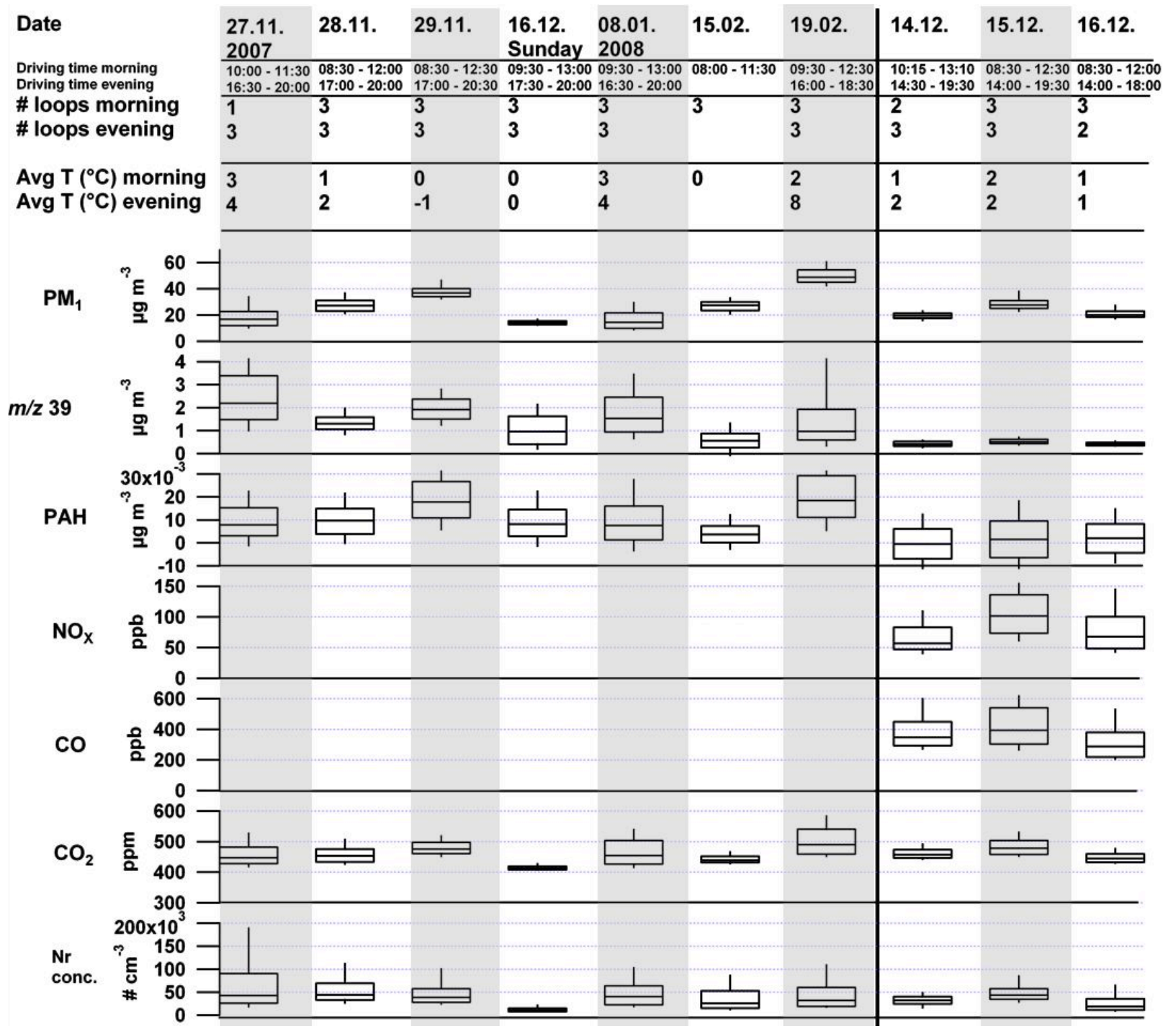

Fig. 1. Overview of drives. Number of loops states how many times the measurement route in Fig. 6 was driven in the given time interval. $\mathrm{PM}_{1}$ includes AMS and MAAP measurements; $\mathrm{m} / \mathrm{z}, 39$ and PAH mass concentrations were measured by Q-AMS. Boxes represent upper and lower quartiles, horizontal lines correspond to the median, and whiskers denote $10 \%$ - and $90 \%$-percentiles. The vertical line shows the division of the dataset into part 1 and part 2. 16 December 2007 is the only Sunday measured, all other days are weekdays.

included 3 loops per half-day. The elevated areas (Buchegg Square - Limmattal Station, $550 \mathrm{~m}$ a.s.l., and Üetliberg, $800 \mathrm{~m}$ a.s.l.) were covered once per half-day. The section leading up to Üetliberg and the one from the main train station to Selnau were only made in December 2008.

\subsection{Mobile laboratory}

Measurements were performed with the PSI mobile laboratory shown in Fig. 2, an IVECO 35S14V Daily van (length $6 \mathrm{~m}$; width $2 \mathrm{~m}$; height $3 \mathrm{~m}$; maximum gross weight 3.5 tons), equipped with a diesel particulate filter which reduces the danger of particulate self-contamination during measurements. The van setup has been described in detail elsewhere (Bukowiecki et al., 2002; Weimer et al., 2009), and only modifications specific for this study will be presented here. The main inlet in front, located at a height of $3.2 \mathrm{~m}$ above ground, consists of a 4-cm inner diameter stainless steel tube. A heavy-duty blower provides a constant flow of $14 \mathrm{~m} \mathrm{~s}^{-1}$ $\left(50 \mathrm{~km} \mathrm{~h}^{-1}\right)$ in the main inlet, eliminating the influence of driving speed. The flow is monitored with an anemometer AM-4203 (Lutron, Taiwan). Despite the turbulent flow in 


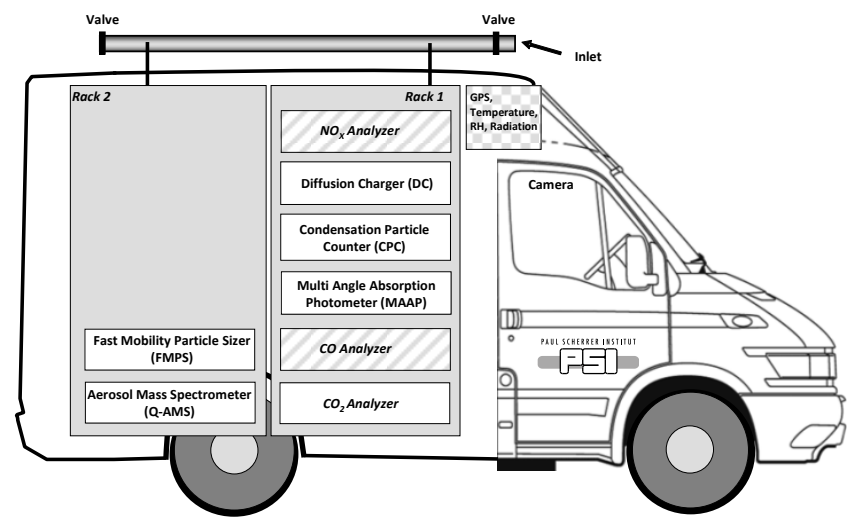

Fig. 2. PSI mobile laboratory. $\mathrm{NO}_{\mathrm{x}}$ analyzer and $\mathrm{CO}$ analyzer were only included in the December 2008 measurements.

this part of the inlet (Reynolds number $R e \sim 42000$ ) particle losses (for particles with a diameter between 50 and $700 \mathrm{~nm}$, a size range where the aerodynamic lens transmission efficiency of the Q-AMS is larger than 50\%, Liu et al., 2007) are negligible $(\leq 0.23 \%$ for diffusion or gravitational losses, $\leq 0.3 \%$ for turbulent diffusion losses), due to the high flow velocity. Two smaller stainless tubes with an inner diameter of $0.8 \mathrm{~cm}$, reaching inside the main inlet tube (in the flow direction, one in front, $10 \mathrm{~cm}$ behind the main inlet entrance, the other one in the back, $250 \mathrm{~cm}$ behind main inlet entrance) distribute the sample air to the two instrument racks (front rack and back rack) inside the van. There is some reduction in flow velocity from the main inlet tube to the tubes reaching the racks (by factors of 2 and 4 for the front and back branching, respectively). Such anisokinetic sampling can lead to an enrichment of larger particles. We did not observe such artifacts during tests with the main inlet flow switched on and off, most likely due to the low size range of the particles measured for this study (for the data taken before December 2008, the Q-AMS was equipped with a high-throughput lens which can potentially reduce the transmission of particles larger than $\sim 400 \mathrm{~nm}$, Hildebrandt et al., 2010). From a common manifold for the front and for the back rack, respectively, copper (or Teflon, for the gas phase instruments) tubing with $0.4 \mathrm{~cm}$ inner diameter led to the different instruments (lengths: $\sim 100 \mathrm{~cm}$ for particle phase, $200-300 \mathrm{~cm}$ for gas phase instruments). Residence time for the aerosol sample varied between 5 and $6 \mathrm{~s}$, depending on the position of the instrument. Due to the high main inlet flow velocity, the difference in residence time between the front and the back rack is negligible $(0.02 \mathrm{~s})$.

\subsection{Instrumentation}

The majority of data presented in this study was collected with the Q-AMS (Aerodyne Research Inc.), providing information on the non-refractory chemical components with a vacuum aerodynamic diameter $\leq 1 \mu \mathrm{m}$, including ammo- nium $\left(\mathrm{NH}_{4}^{+}\right.$, further denoted as $\left.\mathrm{NH}_{4}\right)$, nitrate $\left(\mathrm{NO}_{3}^{-}\right.$, in the following denoted as $\left.\mathrm{NO}_{3}\right)$, sulfate $\left(\mathrm{SO}_{4}^{2-}\right.$, denoted as $\left.\mathrm{SO}_{4}\right)$, chloride $\left(\mathrm{Cl}^{-}\right.$, denoted as $\left.\mathrm{Chl}\right)$, and organics. Polycyclic aromatic hydrocarbons (PAHs, formed during burning or pyrolysis of organic matter in incomplete combustion (Dzepina et al., 2007) were included in total organic mass loadings unless specified differently. Details of the instrument configuration and functioning have been described in numerous publications (Jimenez et al., 2003; Canagaratna et al., 2007). The instrument was operated in the mass spectrum (MS) mode only, with an averaging time of $6 \mathrm{~s}$ (50\% open/closed), scanning an $\mathrm{m} / \mathrm{z}$ range from 1-300. No drier was used prior to Q-AMS sampling, as is generally recommended in order to control RH and particulate phase water. This is an important parameter influencing the collection efficiency of the instrument after the lens (Cross et al., 2009). However, the temperature difference between outside and inside the mobile laboratory has a (varying) drying effect on the sample air, as it reduces relative humidity $(\mathrm{RH})$ inside the van (e.g. for campaign average values from $79 \% \mathrm{RH}$ at $2{ }^{\circ} \mathrm{C}$ outside to $33 \%$ $\mathrm{RH}$ at $\sim 15^{\circ} \mathrm{C}$ inside).

Additional aerosol instruments deployed in the mobile laboratory included a multi angle absorption photometer (MAAP 5012, Thermo), yielding the black carbon (BC) mass concentration with a time resolution of $1 \mathrm{~s}$. For the conversion of the measured light absorption coefficient (at wavelength $\lambda=630 \mathrm{~nm}$ ) to the black carbon mass concentration, a mass specific absorption cross section $\sigma_{\text {abs }}$ of $6.6 \mathrm{~m}^{2} \mathrm{~g}^{-1}$ was used. The particle number concentration was measured with a condensation particle counter (CPC 3010s, TSI) with a time resolution of $1 \mathrm{~s}$. A dilution flow of $91 \mathrm{~min}^{-1}$ was used to extend the upper limit of the concentration range $(0.0001$ to 10000 particles $\mathrm{cm}^{-3}$ ) by a factor of 10 .

$\mathrm{CO}_{2}$ was the only gas phase species measured during all drives of the campaign. A LI-7000 $\mathrm{CO}_{2} / \mathrm{H}_{2} \mathrm{O}$ analyzer (LICOR) measured infrared absorption by $\mathrm{CO}_{2}$ and $\mathrm{H}_{2} \mathrm{O}$. For the days of December 2008, a LMA-3 Luminox Monitor (SCINTREX) was deployed, detecting the presence of $\mathrm{NO}_{2}$ via chemiluminescence (using a luminol solution). A chromium trioxide converter oxidized $\mathrm{NO}$ to $\mathrm{NO}_{2}$ by $\mathrm{CrO}_{3}$ with an average effectiveness of $82 \%$, allowing for the detection of $\mathrm{NO}_{\mathrm{x}}$. $\mathrm{CO}$ was measured for the same period as $\mathrm{NO}_{\mathrm{x}}$ with a carbon monoxide analyzer (Aerolaser $\mathrm{GmbH}$, AL5002). All gas phase measurements were performed with a time resolution of $1 \mathrm{~s}$.

Longitude, latitude, and altitude as well as driving speed were recorded by GPS (Garmin IIplus) with a time resolution of $2 \mathrm{~s}$. Temperature (thermilinear thermistor network, YSI 44203), pressure (device constructed by PSI), RH (HUMICAP sensor, Vaisala HMP 31UT), and global radiation (pyranometer, Kipp\&Zonen "Solarimeter" CM10) were logged with a time resolution of $1 \mathrm{~s}$. 


\subsection{Positive Matrix Factorization (PMF)}

\subsubsection{PMF model: principle}

Source components of the organic fraction measured by QAMS were defined using PMF (Paatero and Tapper, 1993, 1994; Lanz et al., 2007; Ulbrich et al., 2009). PMF is a factor analytical tool whose usefulness in source apportionment of AMS ambient organic data has been proven in numerous studies (e.g. Lanz et al., 2010). Based on Eq. (1), PMF assumes that $x_{i j}$, element in row $i$ (time) and column $j(\mathrm{~m} / \mathrm{z}$ ) of a measured $m \times n$ organic data matrix $\mathbf{X}$, can be modeled as a linear combination of $p$ (number of factors) factor profiles $f_{p j}$ (element of the $p \times n$ matrix $\mathbf{F}$ ) with respective mass contributions $g_{i p}$, element of the $m \times p$ matrix $\mathbf{G}$, plus an error term $e_{i j}$, element of the $m \times n$ residual matrix $\mathbf{E}(\mathbf{E}$ $=\mathbf{X}-\mathbf{G F}) . \mathbf{G}$ and $\mathbf{F}$ are constrained to have non-negative values.

$x_{i j}=\sum_{p} g_{i p} f_{p j}+e_{i j}$

The solution is a weighted iterative least squares fit minimizing $Q$ as in Eq. (2), where the known standard deviations $\sigma_{i j}$ for the values $x_{i j}$ are used for determining the weights of the residuals $e_{i j}$.

$Q=\sum_{i=1}^{m} \sum_{j=1}^{n}\left(e_{i j} / \sigma_{i j}\right)^{2}$

PMF does not require any a priori knowledge regarding sources, but is based on the assumption that factor profiles do not change over time. The model was solved with the PMF2.exe algorithm v.4.2. (Paatero and Tapper, 1994) and results were analyzed using the PMF evaluation tool (PET 2.03A) (Ulbrich et al., 2009).

\subsubsection{Preparatory data analysis for PMF}

Q-AMS data were analyzed using the standard algorithm developed by Allan et al. (2004) (AMS Analysis Toolkit 1.41) within Igor Pro 6 (Wavemetrics, Lake Oswego, OR). The fragmentation table for organics was modified according to Aiken et al. (2008). The CE of the Q-AMS was determined to be 0.85 , based on a comparison of the mass concentrations of the sum of Q-AMS and MAAP data (non-refractory $\mathrm{PM}_{1}$ plus $\mathrm{BC}$ ) with a tapered element oscillating microbalance (TEOM) monitor (Thermo). This comparison was performed in the time period of 27 November 2007 to 10 January 2008. An Aerodyne high-resolution time-of-flight (HRToF-AMS) was measuring at the background site during December 2008. The CE of the HR-ToF-AMS was determined to be 1 (Richard et al., 2011). Q-AMS $(\mathrm{CE}=0.85)$ and HR-ToF-AMS $(\mathrm{CE}=1)$ agreed very well (maximum difference $10 \%$ for all comparison periods). A high ammonium nitrate fraction ( $42 \%$ of total $\mathrm{PM}_{1}$ mass on average) and possible high aerosol water content due to a lack of a specific drying unit in the sample air (see Sect. 2.3) support the relatively high Q-AMS CE. Comparisons of various AMS datasets from all over Europe within the EUCAARI/EMEP project show that ammonium nitrate fractions of $>0.25$ can already lead to a CE above 0.5 (Nemitz et al., 2011). Interestingly, Hildebrandt et al. (2010) found, based on the method by Kostenidou et al. (2007), exactly the same CE for this instrument, when it was operated in Crete.

All data including gas phase species were averaged to $1 \mathrm{~min}$ to match the averaging time chosen for the Q-AMS data. The quadrupole mass spectrometer scans consecutively through mass-to-charge ratios $(\mathrm{m} / \mathrm{z}$ 's) $1-300$, spending a finite time at each $m / z$. As described in Bahreini et al. (2003), particle counting statistics hence impose additional limitation on the signal-to-noise ratio. Assuming that at least 10 particles are required to be detected at each $\mathrm{m} / \mathrm{z}$ for a relevant representative average of the ambient chemical composition, and an aerosol number concentration of $\sim 30000$ (rounded median of all CPC measurements), it takes $0.3 \mathrm{~s}$ ( $14 \mathrm{~s})$ to measure 10 particles (10 "high-mass particles", Jimenez et al., 2003) at a given $m / z$ in MS mode. Hence 1 min averaging time corresponds to a temporal resolution sufficiently low to get a representative sample of the ambient $\mathrm{PM}_{1}$ chemical composition but still high enough in terms of spatial resolution ( $225 \mathrm{~m}$ with a campaign average driving speed of $13.5 \mathrm{~km} \mathrm{~h}^{-1}$ ).

AMS data uncertainties were calculated using the algorithm developed by Allan et al. (2003). Further modification steps of the elements $\sigma_{i j}$ of the uncertainties matrix were done according to the protocol detailed in Ulbrich et al. (2009). $\mathrm{m} / \mathrm{z}$ 's directly proportional to $\mathrm{m} / \mathrm{z} 44 \mathrm{(m} / \mathrm{z}$ 's 16 , 17,18 , and 28) were not downweighted, since downweighting of those variables led to no feasible PMF solution (see Supplement information SI, Fig. SI-1). As stated in Lanz et al. (2007), meteorology plays a dominant role in aerosol mass concentrations during Swiss plateau winters, governing the diurnal pattern of emissions, which makes it difficult for PMF to differentiate between the different factors. Increasing the weight of $m / z 44$ by a factor of 2.24 (the square root of the number of $\mathrm{m} / \mathrm{z}$ 44-related ions, Ulbrich et al., 2009) relative to normally calculated errors was just sufficient a priori information to yield an atmospherically relevant PMF solution. Richard et al. (2011) observed the same for their dataset obtained from stationary measurements in Zurich Kaserne in December 2008.

Due to the time gap between the measurements in winter 2007 and December 2008 and thus varying instrument performance (with an especially bad resolution of the quadrupole mass spectrometer during December 2008 measurements, compare Sect. 3.2), the organic dataset had to be split into two parts for the application of PMF (part 1: measurements days November 2007-February 2008; part 2: December 2008). PMF2 was run in the robust mode (outliers $\left|e_{i j} / \sigma_{i j}\right|>4$ were dynamically reweighted during fitting to 
not pull the fit excessively). The model error (term in the uncertainties estimation proportional to the signal), which is intended to decrease the Q-value for points that do not fit the model, was set to 0 (Ulbrich et al., 2009).

\section{Results}

\subsection{Overview of measurements}

Figure 1 gives information on dates and times of measurements, the number of loops on the measurement route in the corresponding time interval, the mean temperature, as well as an overview on the parameters measured and their variability. The importance of meteorological conditions for the day-to-day variation of the pollutant concentrations becomes evident looking at concentration trends of all measured parameters, all of which follow a roughly similar temporal pattern. Zurich lies on the Swiss plateau, a densely populated region wedged in between the Jura mountains in the north and the Alps in the south. In winter, frequent thermal inversions lead to an entrapment and hence accumulation of emissions and subsequently formed secondary components, resulting in a rather uniform distribution of pollution throughout the whole Swiss plateau region (Lanz et al., 2010).

Figure SI-2 shows such a situation for 29 November 2007, where air masses had been residing over Switzerland for 3 days before arriving at the receptor site. Consequently, the 3 measurement days in November 2007 were characteristic of a gradual accumulation of pollutants, e.g. $\mathrm{PM}_{1}, \mathrm{PAHs}$, and $\mathrm{CO}_{2}$. The decrease in number concentration at the same time could be due to processing of air masses, leading to particle growth through coagulation/condensation.

The Sunday of 16 December 2007 showed low concentrations for all parameters due to fewer emissions (Sunday ban of heavy-duty traffic). 8 January 2008 was the first day after a rainy period, hence particle mass concentrations were low since there was only little time for processing of the air masses and accumulation of pollutants. On 15 February 2008, $\mathrm{m} / \mathrm{z} 39$ (a wood smoke marker with contributions from $\mathrm{K}$ and $\mathrm{C}_{3} \mathrm{H}_{3}^{+}$ions), and $\mathrm{PAH}$ concentrations were particularly low compared to total $\mathrm{PM}_{1}$, most likely due to the fact that measurements were only performed during the morning, and evening emissions from wood burning for domestic heating purposes are usually higher than morning emissions. The highest $\mathrm{PM}_{1}$ concentrations (median $50 \mu \mathrm{g} \mathrm{m}^{-3}$, equal to the Swiss $24 \mathrm{~h}$-legal limit for $\mathrm{PM}_{1}$ that must not be exceeded more than once a year) were recorded on 19 February 2008, a day during a period of stable temperature inversion and subsequent accumulation of pollutants.

Stagnant air masses due to thermal inversion also led to an accumulation of pollutants from 14-15 December 2008. $\mathrm{NO}_{\mathrm{x}}$, in Switzerland mostly emitted from fossil fuel combustion from traffic $(58 \%)$, but also from households $(7 \%)$, industry (25\%), and agriculture (10\%) (BAFU, 2009), showed concentrations up to $100 \mathrm{ppb}$ (median) and $140 \mathrm{ppb}$ (upper quartile) on 15 December, far above the mean value of $30 \mathrm{ppb}$ for December 2008-February 2009 measured at Zurich Kaserne by NABEL. However, it must be taken into account that measurements were performed on road and hence there was a substantial influence by local tailpipe emissions. The median of the $\mathrm{CO}$ concentration, a byproduct of incomplete combustion, were within the range of the annual mean of $0.36 \mathrm{mg} \mathrm{m}^{-3}(\sim 315 \mathrm{ppb})$ (BAFU and EMPA, 2009). Rather high wind speed (up to $4 \mathrm{~m} \mathrm{~s}^{-1}$ ) on 14 December 2008 and a change in meteorological conditions (start of a frontal passage) including breakup of the inversion in the late afternoon of 16 December 2008 led to $\mathrm{PM}_{1}, \mathrm{~m} / z$ 39, PAHs, and number concentrations that were at the lower end of the concentration range for part 2 compared to the other days.

Since mobile measurements are only point measurements in time, the question of representativeness arises. Figure SI3 presents a frequency plot of $\mathrm{PM}_{10}$ daily averages of the periods 1 November 2007-28 February 2008 and 1 December 2008-31 December 2008 at the urban background site Kaserne, with the values corresponding to the days of mobile measurements colored in black. The distribution of the mobile measurement days covers the full range of $\mathrm{PM}_{10}$ mean values, indicating that the chosen days gave a reasonable overview of the concentration range observed in these two winters.

\subsection{PMF results: organic source components}

For both part 1 and part 2 of the organic data matrix measured in Zurich by Q-AMS, three factors were found, attributed to the following components: Hydrocarbon-like organic aerosol (HOA) representing the fraction of organics related to primary traffic emissions; wood burning organic aerosol (WBOA) from wood burning for domestic heating purposes; and oxygenated organic aerosol (OOA), which represents secondary organic aerosol formed by oxidation and condensation of volatile organic precursors (Fig. 3). The mass spectral profiles found independently for the two parts are well correlated: Using the full spectra for the correlation yielded $R^{2}$ values of $0.97,0.97$, and 0.93 for OOA, HOA, and WBOA, respectively; and slopes of 1.04, 1.18, and 1.04 for OOA, HOA, and WBOA, respectively. When correlating the OOA spectra of part 1 and part 2 without the peaks related to $m / z 44$ (i.e., removing $m / z$ 's $16,17,18$, and 28 ), the same $R^{2}$ of 0.97 was found.

The HOA factors show high signals of the ion series $\mathrm{C}_{n} \mathrm{H}_{2 n+1}{ }^{+}(m / z 29,43,57,71, \ldots)$ from saturated alkanes, and $\mathrm{C}_{n} \mathrm{H}_{2 n-1}{ }^{+}(\mathrm{m} / \mathrm{z}, 41,55,69, \ldots)$ from alkenes plus cycloalkanes. Diesel exhaust is typically dominated by recondensed engine lubricating oil and consists mainly of n-alkanes, branched alkanes, cycloalkanes, and aromatics (Canagaratna et al., 2004). Correlation of the HOA factors found here with the standard HOA mass spectral profile from $\mathrm{Ng}$ et al. (2011) yields $R^{2}$ values of 0.98 and 0.9 for part 1 


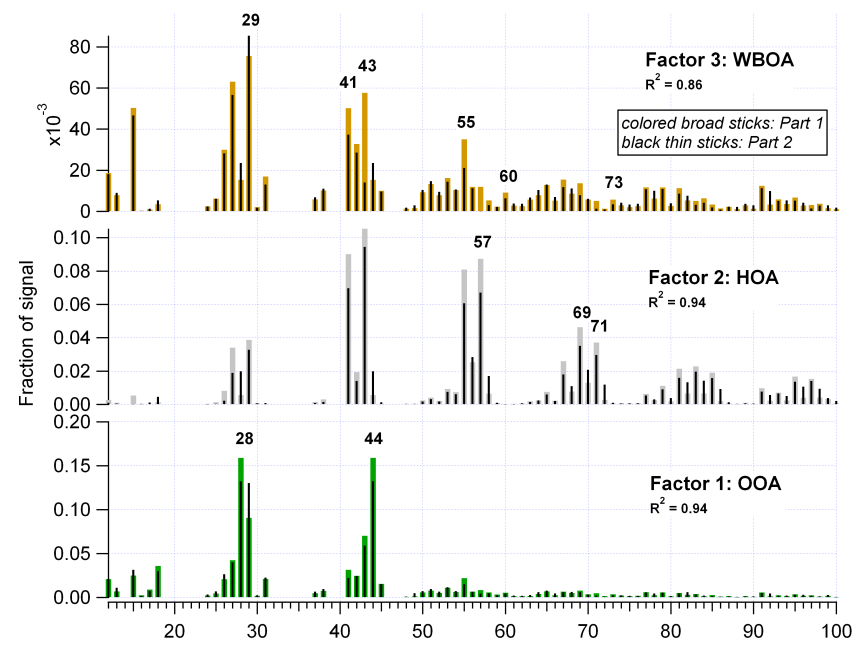

Fig. 3. Normalized mass spectral signatures of factors 1 (OOA), 2 (HOA), 3 (WBOA) of the chosen PMF solution. Colored sticks and black sticks denote results for part 1 and 2 , respectively. $R^{2}$ values quantify similarity of spectra from part 1 and 2 .

and part 2, respectively, showing their high similarity. The factors identified as OOA have their dominant signal at $\mathrm{m} / \mathrm{z}$ 44, which mostly represents $\mathrm{CO}_{2}^{+}$from the thermal decomposition of organic acids (Alfarra, 2004). This is in accordance with previous findings suggesting that the fraction of $\mathrm{m} / \mathrm{z} 44$ in the organic spectra increases with photochemical aging ( $\mathrm{Ng}$ et al., 2010). Comparisons with the standard OOA spectrum from $\mathrm{Ng}$ et al. (2011) show high similarity $\left(R^{2}\right.$ of 0.96 and 0.83 for part 1 and part 2, respectively). $\mathrm{m} / \mathrm{z}$ 's 17 , 18 , and 28 were removed from the fit due to differences in the frag table used here (Aiken et al., 2008). The presence of significant signal at $m / z 60$ in the WBOA spectra helped identify their origin, since $m / z 60$ is attributed to $\mathrm{C}_{2} \mathrm{H}_{4} \mathrm{O}_{2}^{+}$, a fragment of levoglucosan which in turn is a pyrolysis product of cellulose (Alfarra et al., 2007). $R^{2}$ of 0.83 and 0.63 were found for the correlations of the WBOA factors with the standard biomass burning (BBOA) spectrum from $\mathrm{Ng}$ et al. (2011) for part 1 and part 2, respectively.

Rotational ambiguity leads to non-unique solutions still fulfilling the non-negativity constraint (Paatero et al., 2002). The rotational freedom of the chosen solution can be explored through a user-specified rotational parameter fpeak and was chosen to be -0.1 for part 1 , and 0 for part 2 . DeCarlo et al. (2010) explored the solution space for the chosen fpeak running PMF with 50 random initial values (SEED) at iteration start. For the present dataset, SEED values between 0 and 50 yielded two solution groups. For the group not representing the present solution corresponding to $\mathrm{SEED}=0, \mathrm{WBOA}$ and OOA were less clearly separated (Pearson's $R$ value of 0.77 , compared to 0.44 for the present solution). For further detailed discussion of parameters chosen and mathematical criteria for the number of factors determined we refer to the SI, Sect. 4.
For part 2, m/z 29 was removed from the matrix before running PMF due to exceptionally low resolution of the quadrupole mass spectrometer making the separation of neighboring peaks such as $\mathrm{m} / \mathrm{z} 28$ and $\mathrm{m} / \mathrm{z} 29$ difficult. $\mathrm{m} / \mathrm{z}$ 29 was then reintegrated as a linear combination of fractions of the PMF solutions HOA, OOA, and WBOA, respectively, of part 2: The measured time series of $\mathrm{m} / \mathrm{z} 29$ was fit using Eq. (3), where $G_{1}-G_{3}$ represent the time series of factors $1-$ 3 (OOA, HOA, and WBOA)) of the PMF solution, and the resulting $a, b$, and $c$ the fractions of $m / z 29$ of each factor. $e$ denotes an error term.

$f\left(G_{1}, G_{2}, G_{3}\right)=G_{1} a+G_{2} b+G_{3} c+e$

In addition, part 2 comprises fewer data with an overall lower signal-to-noise ratio (SNR) than part 1 (not shown), from 3 days of relatively stable meteorological conditions, making the differentiation of factors more difficult. Especially HOA and WBOA can potentially be difficult for PMF to be separated perfectly, as has been observed by e.g. Aiken et al. (2010) and DeCarlo et al. (2010). For WBOA, the solution chosen for part 2 has lower signal at $m / z$ 's $41,43,55$, and 57 than the part 1 solution. However, choosing an fpeak with a higher fraction of $\mathrm{m} / \mathrm{z} 57$ (fpeak $<0$ ) would lead to a solution with lower signal at $m / z 60$, a marker of biomass burning emissions (see above). For fpeak $=0.1, \mathrm{~m} / \mathrm{z} 60$ in WBOA would be at a maximum, but for fpeak $\geq 0.1$ the contribution from $m / z 44$ in WBOA becomes zero (Fig. SI-11), which is not in accordance with wood burning emission studies (e.g. Heringa et al., 2011).

The results found here are in good agreement $\left(R^{2}\right.$ of 0.99 (0.98), $0.99(0.97)$, and $0.85(0.66)$ for OOA, HOA, and WBOA part 1 (part 2), respectively) with the factors found for stationary measurements at the urban background site Kaserne in January 2006 by Lanz et al. (2008), who used a hybrid receptor model solved by the multilinear engine (ME2) which incorporates a priori known source composition. The same three PMF factors (with $R^{2}$ of 0.98 (0.97), 0.87 (0.86), and 0.87 (0.79) for OOA, HOA, WBOA part 1 (part 2), respectively) were also found by Richard et al. (2011) for a unit mass resolution (UMR) organic dataset again from Zurich Kaserne, measured by a high-resolution time-of-flight AMS in December 2008.

Additional quality assurance of PMF results was done by comparing the time traces of factors 1 to 3 with measured marker mass fragments, inorganic components, and ancillary data (Fig. SI-14-SI-20). Least squares estimates are very sensitive to outliers (non-robust method), and especially the BC data, but also the PMF factor time series of part 2 and gases time series exhibited many spikes. The beforehand mentioned low resolution of the Q-AMS during part 2 measurements led to rather noisy data. In addition, since the data were acquired while moving, short-time concentration peaks could partially be missed due to Q-AMS-specific particle counting statistics (compare Sect. 2.4.2). Hence, the regression analysis of the corresponding time series proved to 
yield too low $R^{2}$ values to confirm a correlation even though they showed similar behavior when plotting the time traces on top of each other. Consequently, data for these comparisons were cleared of outliers (the upper 1st percentile of data was removed) and smoothed using a moving average of 5 data points. Figures SI-19 and SI-20 show the correlations for the corrected and the uncorrected data, respectively. In the following, $R^{2}$ values calculated using smoothed data are in bold. For part1 (part 2), the OOA time trend followed the time series of organic mass fragment $44\left(\mathrm{CO}_{2}^{+}\right), R^{2}=0.99$ (0.80), HOA showed the same time trends as organic mass fragment 57 (mostly $\mathrm{C}_{4} \mathrm{H}_{7}^{+}$, also $\mathrm{C}_{3} \mathrm{H}_{5} \mathrm{O}^{+}$), $R^{2}=0.92(0.88)$, and the WBOA time series followed organic mass fragment $60\left(\mathrm{C}_{2} \mathrm{H}_{4} \mathrm{O}_{2}^{+}\right), R^{2}=0.51(0.42)$. Temporal trends of $\mathrm{BC}$ are more similar to those of HOA $\left(R^{2}=0.65(0.67)\right.$ for part 1 (part 2)) than WBOA $\left(R^{2}=0.18(0.19)\right.$ for part 1 (part 2)). This suggests that traffic emissions contribute more to $\mathrm{PM}_{1}$ $\mathrm{BC}$ than wood burning emissions. This is supported by ${ }^{14} \mathrm{C}$ measurements in winter 2002/2003 in Zurich by Szidat et al. (2009): Fossil fuel usage contributed $75 \%$ and biomass burning $25 \%$ to elemental carbon (EC). For $\mathrm{CO}$ and $\mathrm{NO}_{\mathrm{x}}$, available only for part $2, R^{2}$ values with HOA of 0.42 and 0.73 , respectively, were found, again confirming the relation of HOA to traffic emissions. As observed by Lanz et al. (2008), the OOA time series was correlated with $\mathrm{NH}_{4}$ $\left(R^{2}=0.73(0.35)\right.$ for part 1 (part 2)) and the sum of $\mathrm{NO}_{3}$ and $\mathrm{SO}_{4}\left(R^{2}=0.77(0.39)\right.$ for part 1 (part 2)) rather than with $\mathrm{NO}_{3}$ and $\mathrm{SO}_{4}$ individually, supporting the interpretation of OOA as being mostly secondary. Ambient temperature shows a slight anti-correlation with OOA for part 1 (27 November 2007-8 January 2008: slope $=-0.4, R^{2}=0.3$, see Fig. SI-16 and SI-18), indicating the importance of thermal inversions (with low boundary layer temperatures) for the build-up of secondary particle mass.

\section{3 $\mathrm{PM}_{1}$ chemical composition}

The chemical composition of $\mathrm{PM}_{1}$ (mean per measurement day) is shown as absolute (a) and relative (b) values in Fig. 4, where the dotted black line separates the primary and secondary components. Generally, the ratio of primary to secondary components decreases when total concentrations increase, due to stagnant conditions inhibiting the exchange of air masses and thus allowing for their aging and accumulation of secondary aerosol. Note the difference in relative composition of 16 December 2007 and 8 January 2008, 2 days with similar total concentrations (14 and $17 \mu \mathrm{g} \mathrm{m}^{-3}$, respectively) but different distribution of compounds. On 16 December 2007, a Sunday, traffic emissions were much lower compared to weekdays, due to the dominical ban of heavy-duty trucks, thus the fraction of primary compounds, especially HOA, was very low. In contrast, primary components dominated on 8 January 2008, since there had been only little time to build up secondary aerosol mass follow-
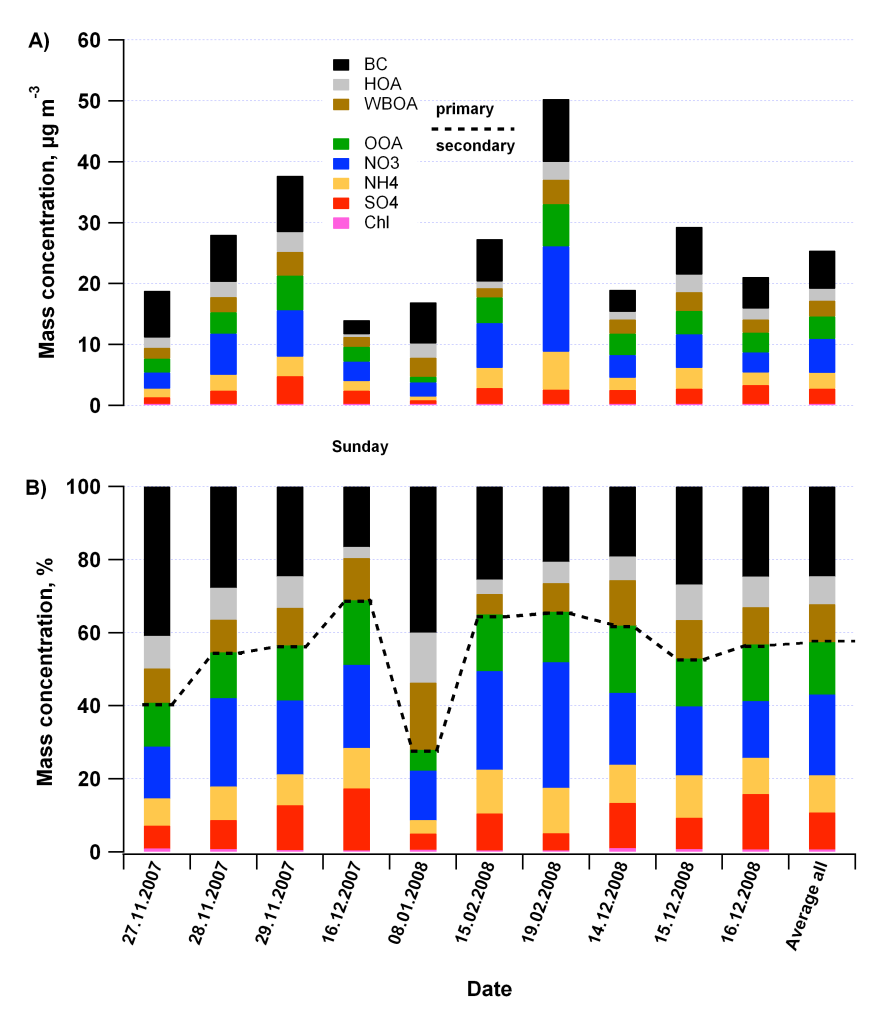

Fig. 4. Absolute (A) and relative (B) composition of $\mathrm{PM}_{1}$, average values per measurement day (complete drive including stops at background station) and average over whole dataset ("average all"). The dashed line shows the proportions of primary and secondary components.

ing washout from precipitation in the preceding days (this is similar for the 27 November 2007 measurements).

Generally, the BC fraction made up $\sim 22 \%$ of total $\mathrm{PM}_{1}$, but this fraction increased substantially for days when primary emissions dominated $\mathrm{PM}_{1}$ composition. OOA constituted the biggest organic fraction (on average $44 \%$ of total organics), as has been found in other places (Jimenez et al., 2009), and WBOA and HOA were less important (32\% and $24 \%$, respectively).

The meteorological conditions during the measurements did not allow for a separation of OOA into a low-volatility and a semi-volatile fraction, OOA-I/LV-OOA and OOAII/SV-OOA, respectively, (Lanz et al., 2007; Hildebrandt et al., 2010) due to relatively small variations in daily temperature and diurnal patterns. However, the degree of oxygenation of OOA can be estimated by plotting the normalized signal at $m / z 44\left(f_{44}\right)$ vs. the normalized signal at $m / z 43\left(f_{43}\right)$ from PMF-OOA spectra (Ng et al., 2010). The PMF-OOA $f_{44}$ and $f_{43}$ values of various datasets acquired all over the world form a triangle (black dotted lines in Fig. 5). The OOA found here lies in the middle of this triangle, and can thus be interpreted as moderately processed OOA with a degree of oxygenation that does not correspond to highly aged air 


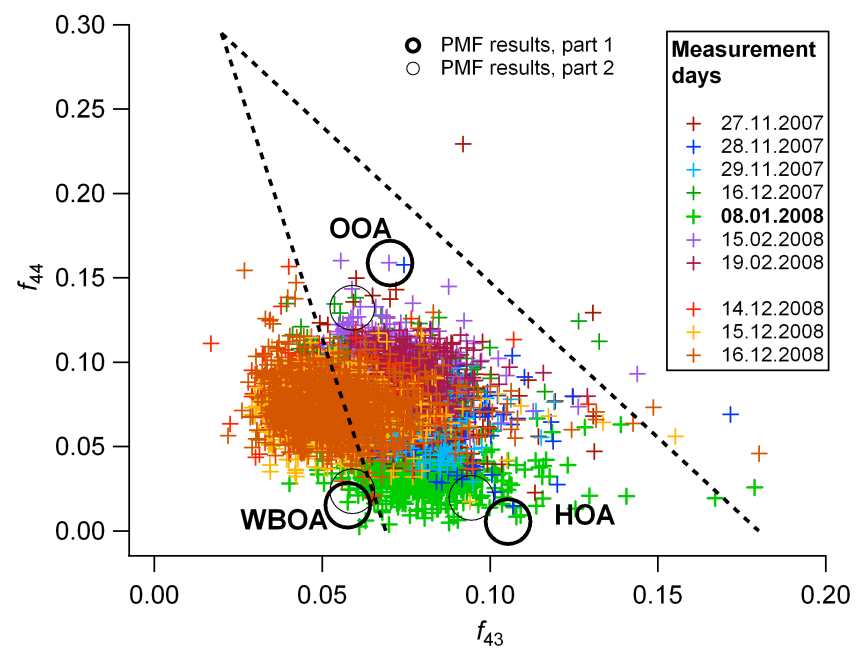

Fig. 5. Fractions of organic mass fragments $44\left(f_{44}\right)$ and $43\left(f_{43}\right)$ in the $\mathrm{Ng}$ triangle ( $\mathrm{Ng}$ et al., 2010), measured. Black circles show the fractions for the resulting spectra from PMF. The measurement day of 8 January 2008 (light green dots) with a low secondary contribution (Fig. 4) shows a lower degree of oxygenation than the other data.

masses. For comparison reasons, the $f_{44} / f_{43}$ values for HOA and WBOA are included as well. In addition, Fig. 5 shows $f_{44} / f_{43}$ values of the measured spectra (where $f_{44}$ and $f_{43}$ also have contributions from HOA and BBOA and thus do not fall fully into the triangle shape). Nevertheless it can be shown that the previously discussed day of 8 January 2008 sticks out (light green), with lower $f_{44}$ and slightly higher $f_{43}$ than the average campaign data, again consistent with this day being dominated by fresh emissions and less aged air masses.

The inorganic fraction is dominated by nitrate, as is common in Swiss winters, when cold temperatures favor ammonium nitrate partitioning into the particle phase (ammonium nitrate formation is unlikely to be limited by ammonia, Andreani-Aksoyoglu et al., 2008).

\subsection{Spatial variation of chemical composition}

Mobile measurements add an additional dimension of space to a dataset. Mapping the spatial variation of $\mathrm{PM}_{1}$ concentration and composition as measured by AMS and MAAP (including the results from the PMF analysis) in Zurich yields a rather consistent picture, with small differences depending on present local primary emission sources or altitude (Fig. 6). On average, the highest mass concentrations were measured on main traffic arteries within city limits (e.g. Rosengarten Street with $47 \mu \mathrm{g} \mathrm{m}^{-3}$ ). Elevated areas such as Höngg $\left(26 \mu \mathrm{g} \mathrm{m}^{-3}\right)$ experience enhanced dilution, or, as Üetliberg, can lie outside the boundary layer and are thus less influenced by emissions from the city. Residential areas and lower traffic roads show similar concentrations throughout the city area between $22 \mu \mathrm{g} \mathrm{m}^{-3}$ (Triemli) and $32 \mu \mathrm{g} \mathrm{m}^{-3}$ (Meierhof Square).

In addition to the homogeneity of overall $\mathrm{PM}_{1}$ concentration, the equally uniform spatial distribution of the chemical composition again confirms the influence of meteorology on air pollution levels as mentioned above. However, a clear distinction can be made between the urban background site "Zurich Kaserne" and the sites covered during mobile measurements. At the background station, $50 \%$ of $\mathrm{PM}_{1}$ are comprised of secondary inorganic compounds such as ammonium nitrate and ammonium sulfate, BC makes up $15 \%$, and the organic fraction is dominated by OOA $(49 \%$ of organics), followed by WBOA (34\%) and HOA (17\%). Lanz et al. (2008) found in their analysis of Zurich Kaserne data 3-13\% HOA, 52-57\% OOA, and 35-40\% WBOA for winter 2006. The differences to the average organic composition measured throughout the city as described in the previous section can be explained by the different setup of measurements - the contribution of HOA is expected to be larger on-road than for stationary measurements at the urban background site. Interestingly, the WBOA fraction was very similar for both the urban background site $(34 \%)$ and on-road $(32 \%)$, implying that the WBOA source is either regional, or well mixed on the local scale due to its emission typically from chimneys and subsequent downmixing. Richard et al. (2011) found a much lower ratio WBOA/HOA (17\%/22\%) for Zurich Kaserne, 1-18 December 2008, and a higher OOA percentage (60\%). During December 2008, homeless people were regularly lighting fires in the late afternoon close to the measurement station. We hypothesize that this led to a local WBOA factor in the solution of Richard et al. (2011), explaining less of the variation of $\mathrm{PM}_{1}$ and ignoring the regional WBOA contribution due to its similar temporal pattern with regional OOA, at least to some extent. To better compare the data from Richard et al. (2011) to our results, the PMF2 algorithm was run on the last part of their dataset only (15-18 December 2008, the period of part 2 of the mobile measurements), when the open fires were banned from the site. The variation of the 3 factor contributions became much more congruent with the results found for this study: HOA $15 \%$, OOA $50 \%$, WBOA $32 \%$ (plus $3 \%$ in the residual).

For the other sites, carbonaceous material (BC, HOA, WBOA, and OOA) makes up the biggest fraction with up to $60 \%$, except for the elevated areas (without Uitikon) where inorganic constituents such as ammonium nitrate and ammonium sulfate constitute more than half of $\mathrm{PM}_{1}$ mass. $\mathrm{BC}$ is the most abundant component, contributing to up to $35 \%$ of $\mathrm{PM}_{1}$ mass on major traffic arteries such as West Street or Rosengarten Street. OOA is the organic compound with the highest concentrations for almost all sites throughout the city. Interestingly, for many sites WBOA concentrations exceed HOA concentrations. The importance of wood burning 


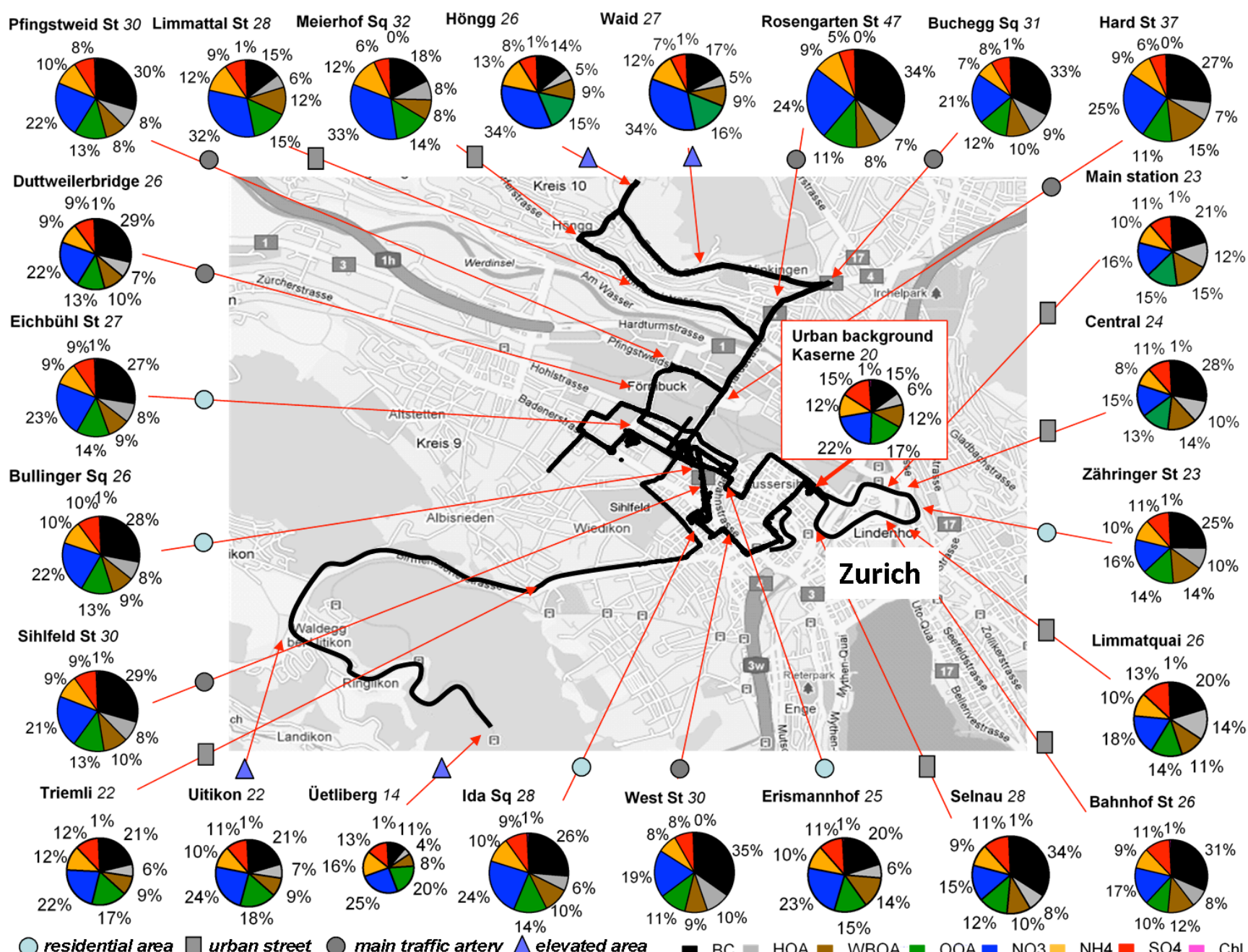

Fig. 6. Spatial variation of the $\mathrm{PM}_{1}$ chemical composition as measured by Q-AMS and MAAP, PMF results included, in the area of Zurich city. Pie areas are relative to total average concentrations from all measurements, absolute concentrations are given in $\mu \mathrm{g} \mathrm{m}^{-3}$ (numbers in italics behind site names). Sites are categorized according to residential areas, urban streets, main traffic arteries, and elevated areas.

emissions in Zurich has already been described by Lanz et al. (2008). Many houses in Zurich feature a fireplace or use exclusively wood for heating purposes, e.g. at the residential area "Erismannhof" where WBOA accounts for $14 \%$ of $\mathrm{PM}_{1}$. The fact that even on major traffic arteries, higher contributions from wood burning than from traffic emissions are often measured, can be explained by wood burning emissions being part of a regional air pollution problem. Switzerland is a country with many rural areas, where wood burning for domestic heating purposes is abundant, and contributes substantially to the overall PM concentrations in the Swiss plateau region during these winter periods. In addition, it has to be taken into account that wood burning as well as traffic emissions have a high potential for the formation of secondary organic aerosol (Chirico et al., 2010; Heringa et al., 2011), possibly doubling or even tripling the primarily emitted organic aerosol mass. Thus, both wood burning and traffic emissions contribute not only with primary emissions to organic $\mathrm{PM}_{1}$ measured in Zurich, but also via OOA on a regional scale.

\subsection{Background versus local contributions}

\subsubsection{Concept}

The distinction and quantification of the fraction of $\mathrm{PM}_{1}$ emitted or formed locally within the city limits, and the fraction of $\mathrm{PM}_{1}$ from the background is of high importance, especially for policy makers implementing mitigation activities. The unique setup of the Zurich mobile measurements campaign featuring an urban background site (Zurich Kaserne) in combination with mobile measurements makes this task possible. As stated earlier, Zurich Kaserne lies in the middle of downtown Zurich but is shielded from direct 
traffic emissions: Its $\mathrm{PM}_{1}$ chemical composition is different from that measured on-road (see Fig. 6) and representative of the urban background pollution. Lenschow et al. (2001) and Querol et al. (2004) showed that in a city area, the background PM concentration ("urban background") is elevated compared to the regional background PM concentration. However, Baltensperger et al. (2002) also showed that this enhancement is more pronounced for primary components (like BC) than for secondary components (like sulfate). When the meteorological conditions favor the buildup of secondary components and a uniform distribution of pollutants throughout the Swiss plateau (as was the case during our mobile measurements) a quite homogenous distribution over rural and background sites may be found also for $\mathrm{PM}_{10}$ or $\mathrm{P}_{2.5}$. Figure SI-21 presents the time series of $\mathrm{PM}_{10}$ (NABEL data) measured at Zurich Kaserne, in Payerne (a rural station $\sim 100 \mathrm{~km}$ southwest of Zurich), and Tänikon (another rural station $\sim 25 \mathrm{~km}$ northeast of Zurich) for the same time intervals as the mobile measurement drives (panel a) and their mean values (panel $b$, error bars denote \pm one standard deviation). The urban background site shows very similar $\mathrm{PM}_{10}$ concentrations $\left(31 \mu \mathrm{g} \mathrm{m}^{-3}\right)$ as the two rural stations Payerne $\left(31 \mu \mathrm{g} \mathrm{m}^{-3}\right)$ and Tänikon $\left(33 \mu \mathrm{g} \mathrm{m}^{-3}\right)$ on the Swiss plateau. Concerning $\mathrm{PM}_{2.5}$, average values for 1416 December 2008 (the days of mobile measurements) were $24.3 \mu \mathrm{g} \mathrm{m}^{-3}$ in Payerne and $25.5 \mu \mathrm{g} \mathrm{m}^{-3}$ at Zurich Kaserne.

Local contributions can be estimated by subtracting the background concentration of component $S$ measured at Kaserne from the on-road concentration of component $S$ measured at the same time. Methodological and dynamicmeteorological constraints impose further modifications of this simple approach. Stationary measurements were always performed at Zurich Kaserne with the mobile laboratory a few minutes before and after a roundtrip of $\sim 1 \mathrm{~h}$. Data acquired during a Kaserne visit were averaged and these mean values were linearly interpolated for the times when measuring on-road. The differences in concentration of components between the background and on-road measurements can be due to either local emissions, immediate formation of secondary components or to small-scale dilution and concentration effects of open squares compared to street canyons (inhomogeneities in the boundary layer). Numerous studies show that street canyons can be characterized by poor ventilation conditions, which in turn lead to high levels of air pollution (Vardoulakis et al., 2003). To assess the latter, a $\mathrm{SO}_{4}$ scaling was introduced. The formation of secondary sulfate is rather slow, the oxidation rate of gaseous $\mathrm{SO}_{2}$ by $\mathrm{OH}$ being lower by a factor of $\sim 10$ compared to $\mathrm{NO}_{2}$ (Sander et al., 2003). The formation of OOA is also more rapid and effective than the sulfate formation. Chirico et al. (2010) and Heringa et al. (2011) have shown in their smog chamber experiments that diesel or wood burning emissions start to form OOA on very short time scales (primary concentrations were more than doubled within $1 \mathrm{~h}$ for a diesel vehicle without aftertreatment, and the organic matter enhancement ratio for wood burning can be up to a factor of 2 after $1 \mathrm{~h}$ ). In addition, $\mathrm{SO}_{2}$ concentrations in Switzerland are very low (mean value in January 2009: $8 \mu \mathrm{g} \mathrm{m}^{-3}$, BAFU and EMPA, 2009). There are no big point sources of $\mathrm{SO}_{2}$ on the Swiss plateau, as there are no refineries and no $\mathrm{SO}_{2}$ emitting power plants. Most important emitters are domestic heating appliances in winter, local small industries, or also emissions from traffic well distributed throughout the region.

The local concentration $S_{1}$ of component $S_{\mathrm{m}}$ measured at time $t$ at position $\mathrm{p}$ is then calculated using Eq. (4), making the following assumptions:

- Secondary formation and primary emissions of $\mathrm{SO}_{4}$ are negligible during the course of one roundtrip $(\sim 1 \mathrm{~h})$.

- Differences in $\mathrm{SO}_{4}$ between Kaserne and measurement point $\mathrm{p}$ are purely due to small-scale meteorological effects.

- The concept is valid only for measurements within the boundary layer.

$S_{\mathrm{l}, t, \mathrm{p}}=S_{\mathrm{m}, t, \mathrm{p}}-\frac{\mathrm{SO}_{4 \mathrm{~m}, t, \mathrm{p}}}{\mathrm{SO}_{4 \mathrm{~b}, t}} \cdot S_{\mathrm{b}, t}$

Subscript $\mathrm{b}$ refers to background (urban background site Kaserne).

In contrast to most other studies investigating urban emissions and their downwind plume (e.g. DeCarlo et al., 2010), our goal was not to assess emissions of the city and their fate downwind, but to assess the differences between local emissions and urban background. The fraction of secondary components formed during one hour will be counted as local, whereas the fraction formed on a longer timescale will be quantified as urban background.

Confirming assumption 3, dilution effects (i.e., intrusion of air masses from above the boundary layer with a different relative composition) in open spaces (as opposed to street canyons) or elevated areas such as Meierhof Square and Üetliberg can lead to concentrations of $S$ at position $\mathrm{p}$ that are lower than at the background site. Thus, the calculated local contribution becomes negative, showing also the limitations of the method presented here. As an alternative approach, local concentrations were also calculated without the $\mathrm{SO}_{4}$ scaling factor (see Fig. SI-22), e.g.

$S_{\mathrm{l}, t, \mathrm{p}}=S_{\mathrm{m}, t, \mathrm{p}}-S_{\mathrm{b}, t}$

Here, the $S_{\mathrm{b}}$ values were not averaged as above, but rather, the interpolated median value of 2 subsequent Kaserne visits was used for the $S_{\mathrm{b}}$ time series. This method decreases the negative local contributions, but also overestimates the local contributions by neglecting the meteorological effects and was thus discarded. Qualitatively, both methods yield similar results, with BC and HOA dominating the local contributions (see Fig. SI-22). Bukowiecki et al. (2002) estimated the background of $\mathrm{CO}$ and particle number concentrations using 
a moving 5-min 5\%-percentile. A similar approach (using a moving 20-min lower $5 \%$-percentile of each $\mathrm{PM}_{1}$ component as background estimate) was also tested for the present dataset, but did not yield meaningful results. Just taking the lowest concentration of individual $\mathrm{PM}_{1}$ components assumes that background and local aerosol compositions are the same, an implication contradicting the observations made here.

\subsubsection{Local contribution of $\mathrm{PM}_{1}$ components: spatial variation}

Figure 7 shows the results for the estimation of local contributions with the $\mathrm{SO}_{4}$ normalization method for different places throughout the city and the mean value for all data in absolute (upper panel a) and relative values (lower panel b). $\mathrm{BC}$ concentrations dominate the composition of the local fraction of $\mathrm{PM}_{1}$ measured in Zurich $\left(1-12 \mu \mathrm{g} \mathrm{m}^{-3}\right.$, making up between $\sim 30$ and $80 \%$ ). HOA also exhibits high local concentrations, adding another $0.5-2.5 \mu \mathrm{g} \mathrm{m}^{-3}$ or $\sim 10-30 \%$ to the local $\mathrm{PM}_{1}$ fraction. It can thus be concluded that traffic is the most important local contributor to $\mathrm{PM}_{1}$ measured on road in Zurich. Concerning WBOA, substantial local contributions can be seen at the residential area "Erismannhof" $\left(1 \mu \mathrm{g} \mathrm{m}^{-3}\right.$ or $30 \%$ of local $\mathrm{PM}_{1}$ ) where wood is exclusively used for heating purposes. Surprisingly, also Bahnhof Street and Hard Street, both busy roads, show enhanced local contributions of WBOA (1-2 $\mu \mathrm{g} \mathrm{m}^{-3}$, or $15-20 \%$ of local $\mathrm{PM}_{1}$, respectively). Residential areas in the vicinity of these roads seem to contribute more to primary organic aerosol (WBOA) than the emissions from traffic (HOA). Overall, compared to the high fractions of WBOA measured in Zurich, its local contributions are rather small. $\mathrm{NO}_{3}$ is the secondary component with the highest local contributions, especially in areas dominated by traffic emissions (up to $1.5 \mu \mathrm{g} \mathrm{m}^{-3}$ or $10 \%$, at Hard Street). This could either be due to the local $\mathrm{NH}_{3}$ emissions of catalyst cars, or due to rapid oxidation of $\mathrm{NO}_{2}$ to $\mathrm{HNO}_{3}$ followed by neutralization with excess $\mathrm{NH}_{3}$, both leading to enhanced $\mathrm{NH}_{4} \mathrm{NO}_{3}$ concentrations measured on road. Overall, mostly primary emissions contribute to local $\mathrm{PM}_{1}$, while secondary aerosol, requiring processing and formation time, is generally part of the background air. For an explanation of negative values we refer to the previous section.

A more general conclusion can be drawn from looking at the percentage of local contributions to measured concentrations for a defined component, or in other words the fraction of a specific aerosol component that is locally emitted or rapidly formed at a specific site. Figure 8 presents the values of these local contributions, averaged over the sites shown in Fig. 7 (the error bars denote \pm standard deviation and show the day-to-day variability of the local contribution fraction, see next paragraph). As stated earlier, primary components from traffic such as BC and HOA exhibit on average (top panel) high local contributions (around 40\%); a similar value (39\%) was obtained for particulate PAHs but is not

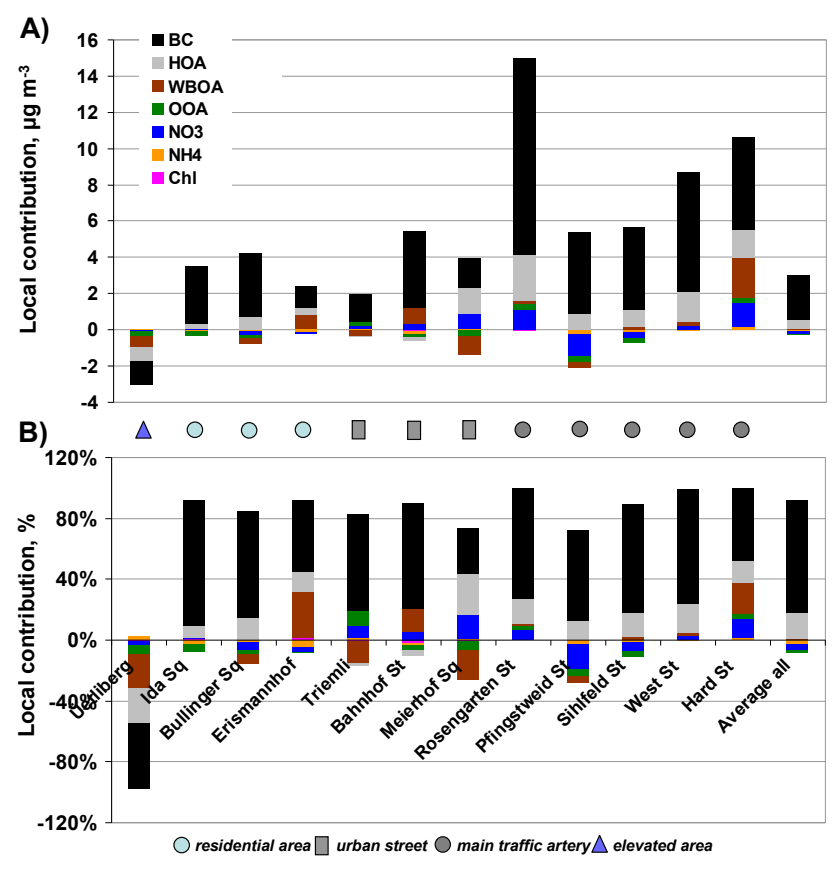

Fig. 7. Local contributions of $\mathrm{PM}_{1}$ components for different sites (absolute values panel (A), relative values panel (B)), averages for the whole campaign are shown. The "average all" bar represents the mean value of the local contribution of all data.

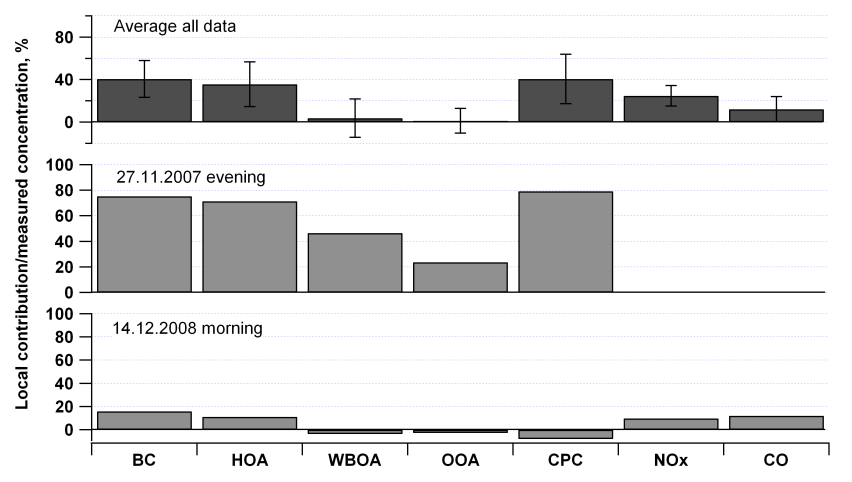

Fig. 8. Percentage of local contributions to total measured concentrations for different components (average of all data \pm 1 standard deviation, top panel) and 2 measurement drives. Note that for $\mathrm{NO}_{\mathrm{x}}$ and $\mathrm{CO}$ (top panel) only part 2 data were included in the average (not measured for part 1). The percentage of background contributions to total measured concentrations can be derived from this plot by subtracting the value denoted by the bars from $100 \%: \sim 60 \%$ for $\mathrm{BC}, \mathrm{HOA}$, and CPC, close to $100 \%$ for $\mathrm{WBOA}$ and OOA, $~ 90 \%$ for $\mathrm{NO}_{\mathrm{X}}$ and $\mathrm{CO}$.

shown here because of large error bars due to very low loadings. In contrast, secondary components such as OOA are almost entirely part of the background pollution. The number concentration (measured by the CPC) shows the same high fraction of local contribution (40\%) as BC and HOA, and can thus also to a great extent be related to traffic emissions. 

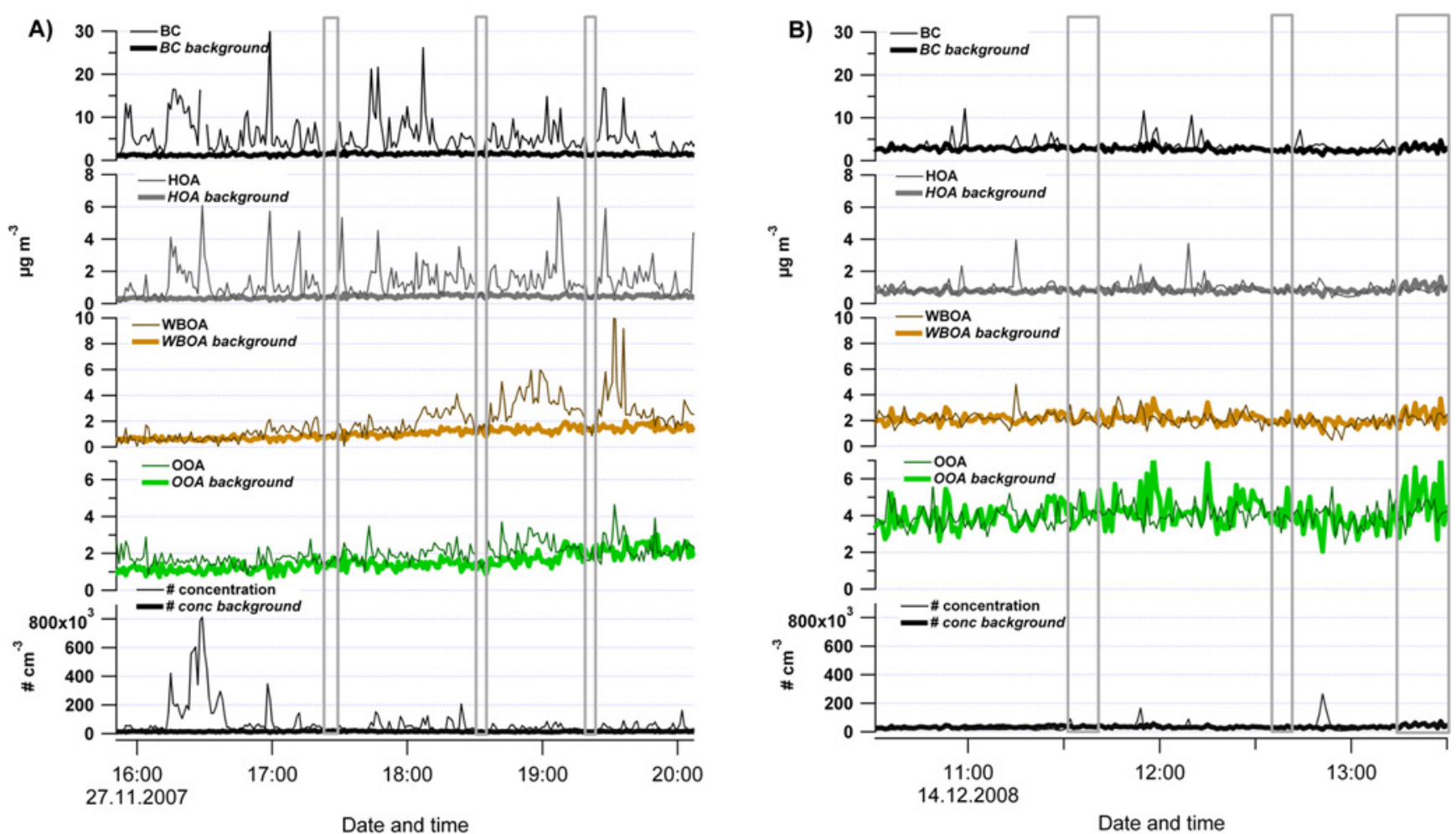

Fig. 9. Time series of measured components and their calculated background concentrations. Panel (A) shows an example drive with high local contributions (big difference between background and measured concentrations), panel (B) an example drive with low local contributions. Grey bars denote periods when measuring at the background station Kaserne.

Interestingly, WBOA, also a primary component, has only very little local contribution in Zurich $(\sim 2 \%$ on average), and is mostly part of the background (see also Richard et al., 2011). Overall, more than half of primary $\mathrm{PM}_{1}$ measured in Zurich during winter cannot be directly related to local emissions. For secondary inorganic components the local portion is even below $6 \%$. This fraction is part of the Swiss plateau wide background air pollution trapped by thermal inversions. Nevertheless, it has to be taken into account that the time intervals considered for the calculation of the background concentration were short (see Sect. 3.5.1., $\sim 1 \mathrm{~h}$ ) and thus secondary aerosol formation time was limited; and that Zurich contributes a large portion, which cannot be quantified, to the background pollution as well (compare Sect. 3.5.1.). For the gas phase species (not shown), the local contributions amount to 20 and $10 \%$ for $\mathrm{NO}_{\mathrm{x}}$ and $\mathrm{CO}$, respectively. These values are lower than the local fractions of the traffic-related particulate emissions, but above the WBOA and OOA contributions. For $\mathrm{CO}_{2}$, the method did not produce valid results, most likely due to the high background level. The alternative background estimation without $\mathrm{SO}_{4}$ scaling yielded a similar pattern, but with 5-10\% higher local contributions, in accordance to the statements made in Sect. 3.5.1.
Figure 8 also compares the magnitude of the local relative contribution for two different days (and scenarios). The middle panel shows the day of 27 November 2007, where the ratio of local contributions to measured concentrations was particularly high, even for the secondary organic fraction (OOA). In contrast, the lowest panel presents the situation for 14 December 2008 where the local contributions are almost non-existent except for the primary, traffic related compounds BC and HOA. Since neither of the two days was a Sunday, a weekday effect can be ruled out for this example. In Fig. 9, the time series of BC, HOA, WBOA, and OOA background and measured concentration are displayed. The day with low local $\mathrm{PM}_{1}$ fractions (right panel) exhibits higher background concentrations (bold lines) than the day with high local contributions (left panel), but also has generally lower total concentrations of components (thin lines), resulting in low local contribution levels. The lower measured concentrations of 14 December 2008 can be explained by higher wind speed than on 27 November $2007\left(3 \mathrm{~m} \mathrm{~s}^{-1}\right.$ compared to $1.3 \mathrm{~m} \mathrm{~s}^{-1}$ ) causing dispersion of primary emissions and by significantly less traffic since rush hour was mostly over when the measurements started. The influence of meteorological parameters such as temperature and wind speed on the magnitude of local contributions was explored in Fig. 10. 

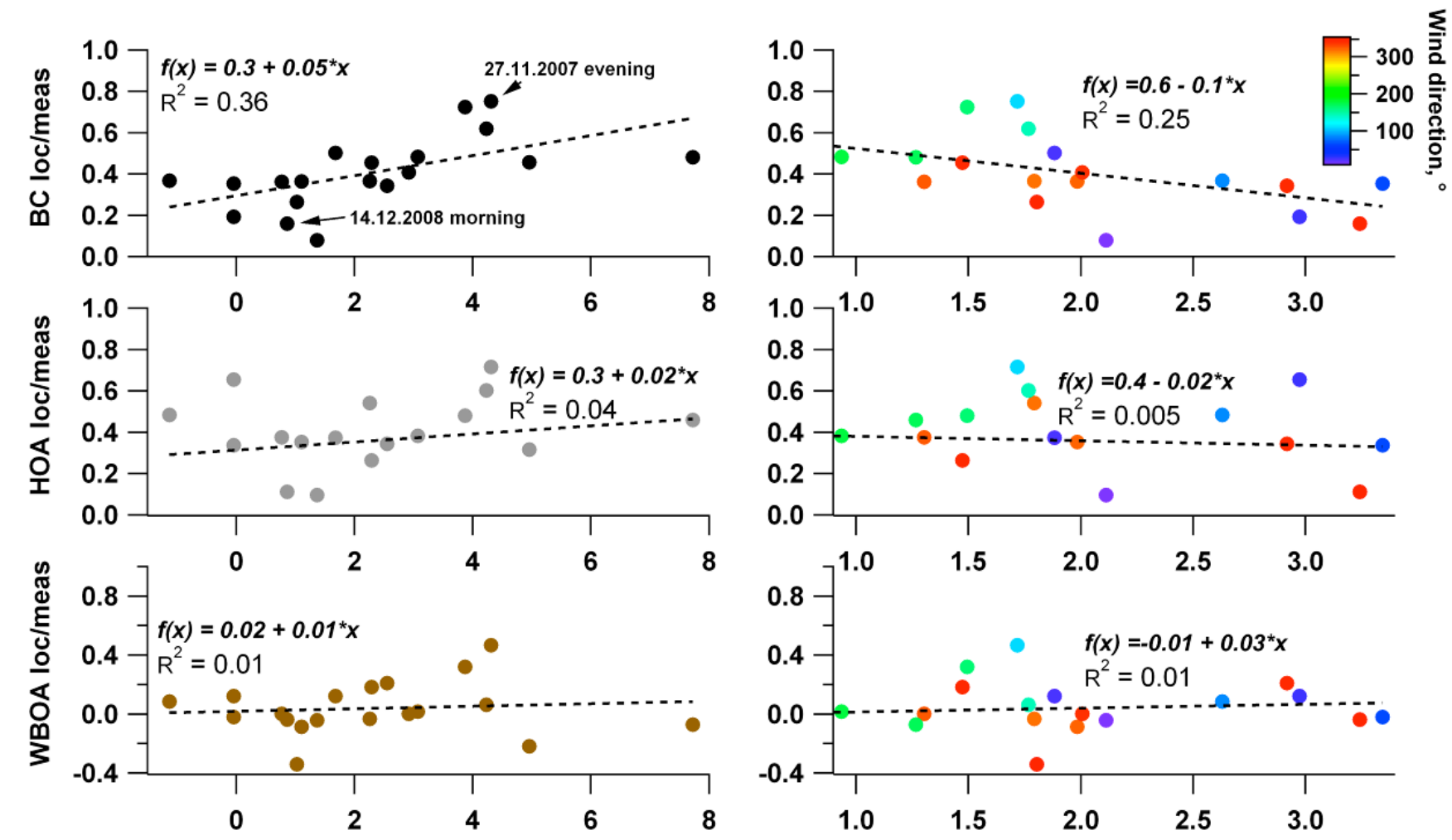

Ambient temperature, ${ }^{\circ} \mathrm{C}$
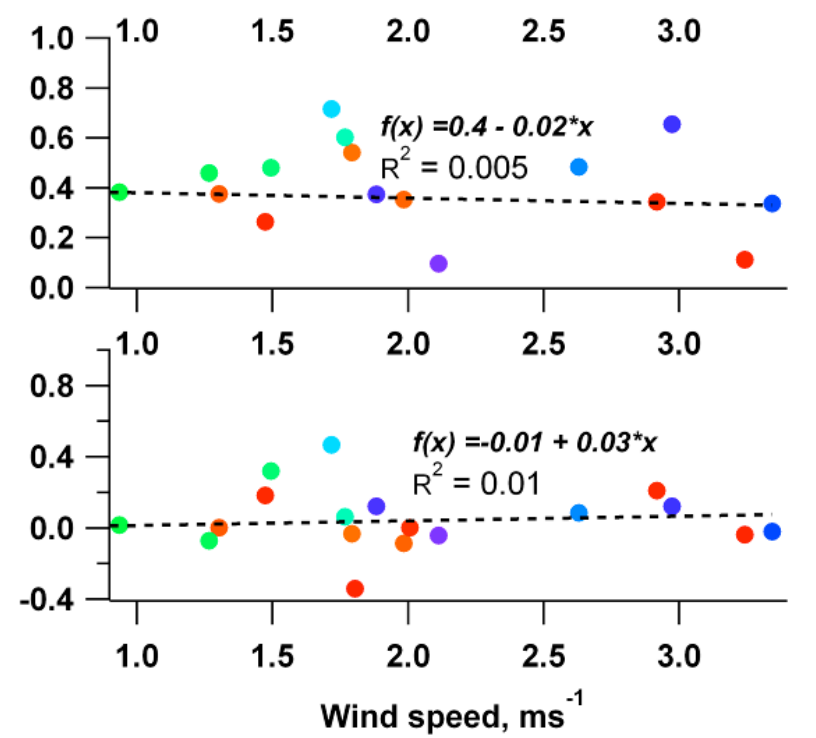

Fig. 10. Ratios of local contributions to measured concentrations of different components as a function of ambient temperature (left) and wind speed (right). Data points are average values per measurement drive. Wind speed data are colored according to wind direction.

No conclusive pattern could be observed for the ratio of lo$\mathrm{cal} /$ measured concentrations (mean values per drive, primary components only) versus temperature, wind speed, or wind direction measured at Kaserne (NABEL data), nor versus temperature differences between Kaserne and Üetliberg (not shown). The weak, slightly positive correlation with temperature and very weak, slightly negative correlation with wind speed of local percentages still points to the link between background concentration levels as seen in Fig. 9 and thermal inversions: As stated earlier, during such conditions, temperatures are low and stagnant air masses (with low wind speeds prevailing) allow for processing of primary $\mathrm{PM}_{1}$ and a buildup of secondary aerosol, thus increasing the background concentrations measured in Zurich and across the Swiss plateau and lowering the ratio local/measured. Hence, the higher the temperature, or the less pronounced the thermal inversion, the higher the ratio of the local/measured concentration.

\section{Conclusions}

On-road mobile measurements of $\mathrm{PM}_{1}$ chemical composition were performed with a Q-AMS and additional instrumentation deployed in the PSI mobile laboratory during win- ter 2007/2008 and December 2008 in the metropolitan area of Zurich, Switzerland. PMF applied to the organic fraction of $\mathrm{PM}_{1}$ yielded 3 different factors assigned to the following sources: Traffic emissions (HOA), emissions from wood burning for domestic heating purposes (WBOA), and an oxygenated fraction (OOA), related to secondary formation of organic aerosol from volatile precursors. On average, OOA made up the biggest organic fraction, followed by WBOA and HOA. Concerning primary emissions, traffic emissions were responsible for high loadings of organic aerosol along major roads and contributed substantially to BC mass loadings, however, domestic wood burning was in general more important than traffic in Zurich during these winter campaigns. The inorganic fraction was dominated by nitrate, as the formation of particulate ammonium nitrate is favored by low temperatures.

Meteorology also plays a major role for the overall total concentration and chemical composition of $\mathrm{PM}_{1}$ as well as the spatial distribution of its constituents. Swiss winters often see thermal inversions over the Swiss plateau between the Jura mountains and the Alps, with emissions being trapped, processed, and accumulating. This leads to a quite uniform distribution of the chemical components in $\mathrm{PM}_{1}$ throughout the region, with small variations throughout the city of 
Zurich depending on elevated areas (dilution), major traffic arteries (high BC, HOA contributions) or residential areas with wood burning emissions. An important question in this context is the separation of the $\mathrm{PM}_{1}$ fraction assigned to very local emissions from the background aerosol, as a help for local authorities in designing mitigation strategies. For this purpose, a method was developed that is based on the particular setup of this campaign, featuring mobile on-road and stationary urban background measurements at the same time. Normalizing the differences between background and on-road measurements to their $\mathrm{SO}_{4}$ ratio accounts for dilution effects due to small-scale meteorology. Results show that $\mathrm{BC}$ and HOA have a substantial local fraction of around $40 \%$. Consequently, traffic related emissions are a large local contributor to $\mathrm{PM}_{1}$ measured on road in Zurich and thus of importance concerning abatement strategies. In contrast, emissions from wood burning have high very local contributions, but are, together with secondary components, to a great extent part of the background. Hence, the reduction of these components requires a regional approach.

Meteorology and especially thermal inversions greatly influence the ratio of local to measured concentrations. Longlasting stagnant conditions lead to an accumulation of $\mathrm{PM}_{1}$ which can dominate the aerosol levels measured in downtown Zurich despite the high anthropogenic activity and the related emissions of air pollutants.

Highly time-resolved mobile measurements of air pollutants provide additional information on the spatial variation of the parameter of interest, here $\mathrm{PM}_{1}$, and hence enable new insights into the distribution, evolution in the atmosphere, and source emission strengths of atmospheric aerosol. Further mobile measurements with the new generation of aerosol mass spectrometers are thus of interest for our understanding of ambient aerosol concentration and composition patterns.

\section{Supplementary material related to this article is available online at: http://www.atmos-chem-phys.net/11/7465/2011/ acp-11-7465-2011-supplement.pdf.}

Acknowledgements. We gratefully acknowledge funding by Imbalance (http://www.cces.ethz.ch/projects/clench/imbalance), by the Swiss Federal Office for the Environment (FOEN), Liechtenstein, Land Vorarlberg (Austria), Ostluft, Cantons Zurich, Graubünden, St. Gallen, and the City of Zurich as well as the Swiss National Science Foundation. Meteorological data at Zurich Kaserne were provided by NABEL (Nationales Beobachtungsnetz für Luftfremdstoffe), a joint project of FOEN and Empa. Peter F. DeCarlo is grateful for the postdoctoral support from the US-NSF (IRFP\# 0701013). We further thank Iakovos Barmpadimos for useful discussions on street canyon dynamics and Dominik Brunner for providing the plot on back air mass back trajectories. We also thank IVECO for providing the van for our mobile laboratory.

Edited by: J. Thornton

\section{References}

Aiken, A. C., DeCarlo, P. F., Kroll, J. H., Worsnop, D. R., Huffman, J. A., Docherty, K. S., Ulbrich, I. M., Mohr, C., Kimmel, J. R., Sueper, D., Sun, Y., Zhang, Q., Trimborn, A., Northway, M., Ziemann, P. J., Canagaratna, M. R., Onasch, T. B., Alfarra, M. R., Prévôt, A. S. H., Dommen, J., Duplissy, J., Metzger, A., Baltensperger, U., and Jimenez, J. L.: O/C and OM/OC ratios of primary, secondary, and ambient organic aerosols with high-resolution time-of-flight aerosol mass spectrometry, Environ. Sci. Technol., 42, 4478-4485, doi:10.1021/Es703009q, 2008.

Aiken, A. C., de Foy, B., Wiedinmyer, C., DeCarlo, P. F., Ulbrich, I. M., Wehrli, M. N., Szidat, S., Prévôt, A. S. H., Noda, J., Wacker, L., Volkamer, R., Fortner, E., Wang, J., Laskin, A., Shutthanandan, V., Zheng, J., Zhang, R., Paredes-Miranda, G., Arnott, W. P., Molina, L. T., Sosa, G., Querol, X., and Jimenez, J. L.: Mexico city aerosol analysis during MILAGRO using high resolution aerosol mass spectrometry at the urban supersite (T0) - Part 2: Analysis of the biomass burning contribution and the non-fossil carbon fraction, Atmos. Chem. Phys., 10, 5315-5341, doi:10.5194/acp-10-5315-2010, 2010.

Alfarra, M. R.: Insights into Atmospheric Organic Aerosols using an aerosol mass spectrometer, $\mathrm{PhD}$, Institute of Science and Technology, University of Manchester, Manchester, 2004.

Alfarra, M. R., Prévôt, A. S. H., Szidat, S., Sandradewi, J., Weimer, S., Lanz, V. A., Schreiber, D., Mohr, M., and Baltensperger, U.: Identification of the mass spectral signature of organic aerosols from wood burning emissions, Environ. Sci. Technol., 41, 57705777, 2007.

Allan, J. D., Jimenez, J. L., Williams, P. I., Alfarra, M. R., Bower, K. N., Jayne, J. T., Coe, H., and Worsnop, D. R.: Quantitative sampling using an aerodyne aerosol mass spectrometer: 1 . Techniques of data interpretation and error analysis, J. Geophys. Res.Atmos., 108, D34090, doi:10.1029/2002JD002358, 2003.

Allan, J. D., Delia, A. E., Coe, H., Bower, K. N., Alfarra, M. R., Jimenez, J. L., Middlebrook, A. M., Drewnick, F., Onasch, T. B., Canagaratna, M. R., Jayne, J. T., and Worsnop, D. R.: A generalised method for the extraction of chemically resolved mass spectra from aerodyne aerosol mass spectrometer data, J. Aerosol. Sci., 35, 909-922, 2004.

Andreani-Aksoyoglu, S., Keller, J., Prévôt, A. S. H., Baltensperger, U., and Flemming, J.: Secondary aerosols in Switzerland and northern Italy: Modeling and sensitivity studies for summer 2003, J. Geophys. Res., 113, D06303, doi:10.1029/2007JD009053, 2008.

BAFU and EMPA: NABEL Luftbelastung 2008, Messresultate des nationalen Beobachtungsnetzes für Luftfremdstoffe (NABEL), 2009.

Bahreini, R., Jimenez, J. L., Wang, J., Flagan, R. C., Seinfeld, J. H., Jayne, J. T., and Worsnop, D. R.: Aircraft-based aerosol size and composition measurements during ACE-Asia using an Aerodyne aerosol mass spectrometer, J. Geophys. Res.-Atmos., 108, D238645, doi:10.1029/2002jd003226, 2003.

Baldasano, J. M., Valera, E., and Jiménez, P.: Air quality data from large cities, Sci. Total Environ., 307, 141-165, 2003.

Baltensperger, U., Streit, N., Weingartner, E., Nyeki, S., Prévôt, A. S. H., Van Dingenen, R., Virkkula, A., Putaud, J. P., Even, A., ten Brink, H., Blatter, A., Neftel, A., and Gäggeler, H. W.: Urban and rural aerosol characterization of summer smog events 
during the PIPAPO field campaign in Milan, Italy, J. Geophys. Res., 107, D228193, doi:10.1029/2001JD001292, 2002.

Baltensperger, U., Chirico, R., DeCarlo, P. F., Dommen, J., Gaeggeler, K., Heringa, M. F., Li, M. L., Prévôt, A. S. H., Alfarra, M. R., Gross, D. S., and Kalberer, M.: Recent developments in the mass spectrometry of atmospheric aerosols, Eur. J. Mass Spectrom., 16, 389-395, 2010.

Bukowiecki, N., Dommen, J., Prévôt, A. S. H., Richter, R., Weingartner, E., and Baltensperger, U.: A mobile pollutant measurement laboratory-measuring gas phase and aerosol ambient concentrations with high spatial and temporal resolution, Atmos. Environ., 36, 5569-5579, 2002.

Bukowiecki, N., Dommen, J., Prévôt, A. S. H., Weingartner, E., and Baltensperger, U.: Fine and ultrafine particles in the Zürich (Switzerland) area measured with a mobile laboratory: an assessment of the seasonal and regional variation throughout a year, Atmos. Chem. Phys., 3, 1477-1494, doi:10.5194/acp-3-1477-2003, 2003.

Bukowiecki, N., Lienemann, P., Hill, M., Furger, M., Richard, A., Amato, F., Prévôt, A. S. H., Baltensperger, U., Buchmann, B., and Gehrig, R.: PM 10 emission factors for non-exhaust particles generated by road traffic in an urban street canyon and along a freeway in Switzerland, Atmos. Environ., 44, 2330-2340, 2010.

Canagaratna, M. R., Jayne, J. T., Ghertner, D. A., Herndon, S., Shi, Q., Jimenez, J. L., Silva, P. J., Williams, P., Lanni, T., Drewnick, F., Demerjian, K. L., Kolb, C. E., and Worsnop, D. R.: Chase studies of particulate emissions from in-use New York City vehicles, Aerosol. Sci. Technol., 38, 555-573, 2004.

Canagaratna, M. R., Jayne, J. T., Jimenez, J. L., Allan, J. D., Alfarra, M. R., Zhang, Q., Onasch, T. B., Drewnick, F., Coe, H., Middlebrook, A., Delia, A., Williams, L. R., Trimborn, A. M., Northway, M. J., DeCarlo, P. F., Kolb, C. E., Davidovits, P., and Worsnop, D. R.: Chemical and microphysical characterization of ambient aerosols with the aerodyne aerosol mass spectrometer, Mass Spectrom. Rev., 26, 185-222, 2007.

Chirico, R., DeCarlo, P. F., Heringa, M. F., Tritscher, T., Richter, R., Prévôt, A. S. H., Dommen, J., Weingartner, E., Wehrle, G., Gysel, M., Laborde, M., and Baltensperger, U.: Impact of aftertreatment devices on primary emissions and secondary organic aerosol formation potential from in-use diesel vehicles: results from smog chamber experiments, Atmos. Chem. Phys., 10, 11545-11563, doi:10.5194/acp-10-11545-2010, 2010.

Cross, E. S., Onasch, T. B., Canagaratna, M., Jayne, J. T., Kimmel, J., Yu, X.-Y., Alexander, M. L., Worsnop, D. R., and Davidovits, P.: Single particle characterization using a light scattering module coupled to a time-of-flight aerosol mass spectrometer, Atmos. Chem. Phys., 9, 7769-7793, doi:10.5194/acp-9-7769-2009, 2009.

DeCarlo, P. F., Dunlea, E. J., Kimmel, J. R., Aiken, A. C., Sueper, D., Crounse, J., Wennberg, P. O., Emmons, L., Shinozuka, Y., Clarke, A., Zhou, J., Tomlinson, J., Collins, D. R., Knapp, D., Weinheimer, A. J., Montzka, D. D., Campos, T., and Jimenez, J. L.: Fast airborne aerosol size and chemistry measurements above Mexico City and Central Mexico during the MILAGRO campaign, Atmos. Chem. Phys., 8, 4027-4048, doi:10.5194/acp8-4027-2008, 2008.

DeCarlo, P. F., Ulbrich, I. M., Crounse, J., de Foy, B., Dunlea, E. J., Aiken, A. C., Knapp, D., Weinheimer, A. J., Campos, T., Wennberg, P. O., and Jimenez, J. L.: Investigation of the sources and processing of organic aerosol over the Central Mexican Plateau from aircraft measurements during MILAGRO, Atmos. Chem. Phys., 10, 5257-5280, doi:10.5194/acp-10-52572010, 2010.

Dzepina, K., Arey, J., Marr, L. C., Worsnop, D. R., Salcedo, D., Zhang, Q., Onasch, T. B., Molina, L. T., Molina, M. J., and Jimenez, J. L.: Detection of particle-phase polycyclic aromatic hydrocarbons in Mexico City using an aerosol mass spectrometer, Int. J. Mass Spectrom., 263, 152-170, 2007.

Gehrig, R. and Buchmann, B.: Characterising seasonal variations and spatial distribution of ambient $\mathrm{PM}_{10}$ and $\mathrm{PM}_{2.5}$ concentrations based on long-term Swiss monitoring data, Atmos. Environ., 37, 2571-2580, doi:10.1016/S1352-2310(03)00221-8, 2003.

Gehrig, R., Hueglin, C., Devos, W., Hofer, P., Kobler, J., Stahel, W. A., Baltensperger, U., and Monn, C.: Contribution of road traffic to ambient fine particle concentrations $\left(\mathrm{PM}_{10}\right)$ in Switzerland, 1-4, Inderscience, Geneva, SUISSE, 2001.

Heringa, M. F., DeCarlo, P. F., Chirico, R., Tritscher, T., Dommen, J., Weingartner, E., Richter, R., Wehrle, G., Prévôt, A. S. H., and Baltensperger, U.: Investigations of primary and secondary particulate matter of different wood combustion appliances with a high-resolution time-of-flight aerosol mass spectrometer, Atmos. Chem. Phys., 11, 5945-5957, doi:10.5194/acp-11-59452011, 2011.

Hildebrandt, L., Engelhart, G. J., Mohr, C., Kostenidou, E., Lanz, V. A., Bougiatioti, A., DeCarlo, P. F., Prévôt, A. S. H., Baltensperger, U., Mihalopoulos, N., Donahue, N. M., and Pandis, S. N.: Aged organic aerosol in the Eastern Mediterranean: the Finokalia Aerosol Measurement Experiment - 2008, Atmos. Chem. Phys., 10, 4167-4186, doi:10.5194/acp-10-4167-2010, 2010.

Hueglin, C., Gehrig, R., Baltensperger, U., Gysel, M., Monn, C., and Vonmont, H.: Chemical characterisation of $\mathrm{PM}_{2.5}, \mathrm{PM}_{10}$ and coarse particles at urban, near-city and rural sites in Switzerland, Atmos. Environ., 39, 637-651, 2005.

IPCC: Fourth Assessment Report: The Physical Science Basis, Working Group I, Final Report, Geneva, Switzerland, available at: http://www.ipcc.ch/ipccreports/ar4-wg1.htm, 2007.

Jimenez, J. L., Jayne, J. T., Shi, Q., Kolb, C. E., Worsnop, D. R., Yourshaw, I., Seinfeld, J. H., Flagan, R. C., Zhang, X. F., Smith, K. A., Morris, J. W., and Davidovits, P.: Ambient aerosol sampling using the Aerodyne aerosol mass spectrometer, J. Geophys. Res.-Atmos., 108, D78425, doi:10.1029/2001JD001213, 2003.

Jimenez, J. L., Canagaratna, M. R., Donahue, N. M., Prévôt, A. S. H., Zhang, Q., Kroll, J. H., DeCarlo, P. F., Allan, J. D., Coe, H., Ng, N. L., Aiken, A. C., Docherty, K. S., Ulbrich, I. M., Grieshop, A. P., Robinson, A. L., Duplissy, J., Smith, J. D., Wilson, K. R., Lanz, V. A., Hueglin, C., Sun, Y. L., Tian, J., Laaksonen, A., Raatikainen, T., Rautiainen, J., Vaattovaara, P., Ehn, M., Kulmala, M., Tomlinson, J. M., Collins, D. R., Cubison, M. J., Dunlea, E. J., Huffman, J. A., Onasch, T. B., Alfarra, M. R., Williams, P. I., Bower, K., Kondo, Y., Schneider, J., Drewnick, F., Borrmann, S., Weimer, S., Demerjian, K., Salcedo, D., Cottrell, L., Griffin, R., Takami, A., Miyoshi, T., Hatakeyama, S., Shimono, A., Sun, J. Y., Zhang, Y. M., Dzepina, K., Kimmel, J. R., Sueper, D., Jayne, J. T., Herndon, S. C., Trimborn, A. M., Williams, L. R., Wood, E. C., Middlebrook, A. M., Kolb, C. E., Baltensperger, U., and Worsnop, D. R.: Evolution of organic aerosols in the atmosphere, Science, 326, 1525-1529, 2009. 
Krecl, P., Strom, J., and Johansson, C.: Diurnal variation of atmospheric aerosol during the wood combustion season in Northern Sweden, Atmos. Environ., 42, 4113-4125, 2008.

Lanz, V. A., Alfarra, M. R., Baltensperger, U., Buchmann, B., Hueglin, C., and Prévôt, A. S. H.: Source apportionment of submicron organic aerosols at an urban site by factor analytical modelling of aerosol mass spectra, Atmos. Chem. Phys., 7, 1503-1522, doi:10.5194/acp-7-1503-2007, 2007.

Lanz, V. A., Alfarra, M. R., Baltensperger, U., Buchmann, B., Hueglin, C., Szidat, S., Wehrli, M. N., Wacker, L., Weimer, S., Caseiro, A., Puxbaum, H., and Prévôt, A. S. H.: Source attribution of submicron organic aerosols during wintertime inversions by advanced factor analysis of aerosol mass spectra, Environ. Sci. Technol., 42, 214-220, doi:10.1021/Es0707207, 2008.

Lanz, V. A., Prévôt, A. S. H., Alfarra, M. R., Weimer, S., Mohr, C., DeCarlo, P. F., Gianini, M. F. D., Hueglin, C., Schneider, J., Favez, O., D'Anna, B., George, C., and Baltensperger, U.: Characterization of aerosol chemical composition with aerosol mass spectrometry in Central Europe: an overview, Atmos. Chem. Phys., 10, 10453-10471, doi:10.5194/acp-10-10453-2010, 2010.

Lenschow, P., Abraham, H. J., Kutzner, K., Lutz, M., Preuß, J. D., and Reichenbächer, W.: Some ideas about the sources of $\mathrm{PM}_{10}$, Atmos. Environ., 35, 23-33, 2001.

Liu, P. S. K., Deng, R., Smith, K. A., Williams, L. R., Jayne, J. T., Canagaratna, M. R., Moore, K., Onasch, T. B., Worsnop, D. R., and Deshler, T.: Transmission efficiency of an aerodynamic focusing lens system: Comparison of model calculations and laboratory measurements for the Aerodyne aerosol mass spectrometer, Aerosol. Sci. Technol., 41, 721-733, 2007.

Mejía, J. F., Morawska, L., and Mengersen, K.: Spatial variation in particle number size distributions in a large metropolitan area, Atmos. Chem. Phys., 8, 1127-1138, doi:10.5194/acp-8-11272008, 2008.

Molina, M. J. and Molina, L. T.: Megacities and atmospheric pollution, J. Air Waste Manage., 54, 644-680, 2004.

Molina, L. T., Madronich, S., Gaffney, J. S., Apel, E., de Foy, B., Fast, J., Ferrare, R., Herndon, S., Jimenez, J. L., Lamb, B., Osornio-Vargas, A. R., Russell, P., Schauer, J. J., Stevens, P. S., Volkamer, R., and Zavala, M.: An overview of the MILAGRO 2006 Campaign: Mexico City emissions and their transport and transformation, Atmos. Chem. Phys., 10, 8697-8760, doi:10.5194/acp-10-8697-2010, 2010.

Nemitz, E., Prévôt, A. S. H., Äijälä, M., Allan, J. D., Berresheim, H., Carbone, S., Canagaratna, M. R., Capes, G., Ceburnis, D., Choularton, T., Coe, H., Cubison, M. J., Dall'Osto, M., Di Marco, C. F., DeCarlo, P. F., Ehn, M., Eriksson, A., Freney, E., Herrmann, H., Jimenez, J. L., Hildebrandt, L., Juninen, H., Kiendler-Scharr, A., Laaksonen, A., Lanz, V. A., McFiggans, G., Mensah, A., Mentel, T. F., Mohr, C., O’Dowd, C., Ortega, A., Ovadnevaite, J., Pagels, J., Pandis, S. N., Phillips, G. J., Poulain, L., Raatikainen, T., Saarikoski, S., Sellegri, K., Spindler, G., Sueper, D., Swietlicki, E., Tiitta, P., and Worsnop, D. R.: European submicron aerosol chemical composition derived from a campaign-based Aerosol Mass Spectrometer network, in preparation, 2011.

Ng, N. L., Canagaratna, M. R., Zhang, Q., Jimenez, J. L., Tian, J., Ulbrich, I. M., Kroll, J. H., Docherty, K. S., Chhabra, P. S., Bahreini, R., Murphy, S. M., Seinfeld, J. H., Hildebrandt, L., Donahue, N. M., DeCarlo, P. F., Lanz, V. A., Prévôt, A. S. H.,
Dinar, E., Rudich, Y., and Worsnop, D. R.: Organic aerosol components observed in Northern Hemispheric datasets from Aerosol Mass Spectrometry, Atmos. Chem. Phys., 10, 46254641, doi:10.5194/acp-10-4625-2010, 2010.

Ng, N. L., Canagaratna, M. R., Jimenez, J. L., Zhang, Q., Ulbrich, I. M., and Worsnop, D. R.: Real-time methods for estimating organic component mass concentrations from aerosol mass spectrometer data, Environ. Sci. Technol., 45, 910-916, 2011.

Paatero, P. and Tapper, U.: Analysis of Different Modes of FactorAnalysis as Least-Squares Fit Problems, Chemometr. Intell. Lab., 18, 183-194, 1993.

Paatero, P. and Tapper, U.: positive matrix factorization - a nonnegative factor model with optimal utilization of error-estimates of data values, Environmetrics, 5, 111-126, 1994.

Paatero, P., Hopke, P. K., Song, X. H., and Ramadan, Z.: Understanding and controlling rotations in factor analytic models, Chemometr. Intell. Lab., 60, 253-264, 2002.

Pandolfi, M., Querol, X., Alastuey, A., Jimenez, J. L., Cusack, M., Reche, C., Pey, J., Mohr, C., DeCarlo, P. F., Ortega, A., Day, D., Prévôt, A. S. H., Baltensperger, U., Artiñano, B., Baldasano, J. M., Jorba, O., Burkhart, J., Hansel, A., Schallhart, S., Müller, M., Metzger, M., Saarikoski, S., Cubison, M. J., Ng, S., Lorente, J., Nemitz, E., Di Marco, C., Peñuelas, J., Sicard, M., Comeron, A., Amato, F., Moreno, T., Viana , M., Pérez, N., Moreno, N., Seco, R., Filella, I., Llusià, J., Piot, M., and Pay, M. T.: Sources and origin of PM in the Western Mediterranean Basin: An overview of the DAURE campaign, in preparation, 2011.

Pope, C. A. and Dockery, D. W.: Health effects of fine particulate air pollution: Lines that connect, J. Air Waste Manage., 56, 709742, 2006.

Posfai, M. and Buseck, P. R.: Nature and climate effects of individual tropospheric aerosol particles, Ann. Rev. Earth Planet. Sc., $38,17-43,2010$.

Querol, X., Alastuey, A., Ruiz, C. R., Artiñano, B., Hansson, H. C., Harrison, R. M., Buringh, E., ten Brink, H. M., Lutz, M., Bruckmann, P., Straehl, P., and Schneider, J.: Speciation and origin of $\mathrm{PM}_{10}$ and $\mathrm{PM}_{2.5}$ in selected European cities, Atmos. Environ., 38, 6547-6555, 2004.

Richard, A., Gianini, M. F. D., Mohr, C., Furger, M., Bukowiecki, N., Minguillón, M. C., Lienemann, P., Flechsig, U., Appel, K., DeCarlo, P. F., Heringa, M. F., Chirico, R., Baltensperger, U., and Prévôt, A. S. H.: Source apportionment of size and time resolved trace elements and organic aerosols from an urban courtyard site in Switzerland, Atmos. Chem. Phys. Discuss., 11, 3727-3776, doi:10.5194/acpd-11-3727-2011, 2011.

Sander, S. P., Golden, D. M., Kurylo, M. J., Huie, R. E., Orkin, V. L., Moortgat, G. K., Ravishankara, A. R., Kolb, C. E., Molina, M. J., and Finlayson-Pitts, B. J.: Chemical kinetics and photochemical data for use in atmospheric studies, Evaluation 14, Jet Propulsion Laboratory, Pasadena, CA, available at: http: //jpldataeval.jpl.nasa.gov, 2003.

Schneider, J., Hings, S. S., Hock, B. N., Weimer, S., Borrmann, S., Fiebig, M., Petzold, A., Busen, R., and Karcher, B.: Aircraftbased operation of an aerosol mass spectrometer: Measurements of tropospheric aerosol composition, J. Aerosol. Sci., 37, 839857, doi:10.1016/j.jaerosci.2005.07.002, 2006.

Szidat, S., Jenk, T. M., Synal, H. A., Kalberer, M., Wacker, L., Hajdas, I., Kasper-Giebl, A., and Baltensperger, U.: Contributions of fossil fuel, biomass-burning, and biogenic emissions to 
carbonaceous aerosols in Zurich as traced by C-14, J. Geophys. Res.-Atmos., 111, D07206, doi:10.1029/2005JD006590, 2006.

Szidat, S., Ruff, M., Perron, N., Wacker, L., Synal, H.-A., Hallquist, M., Shannigrahi, A. S., Yttri, K. E., Dye, C., and Simpson, D.: Fossil and non-fossil sources of organic carbon (OC) and elemental carbon (EC) in Göteborg, Sweden, Atmos. Chem. Phys., 9, 1521-1535, doi:10.5194/acp-9-1521-2009, 2009.

Thornhill, D. A., Williams, A. E., Onasch, T. B., Wood, E., Herndon, S. C., Kolb, C. E., Knighton, W. B., Zavala, M., Molina, L. T., and Marr, L. C.: Application of positive matrix factorization to on-road measurements for source apportionment of diesel- and gasoline-powered vehicle emissions in Mexico City, Atmos. Chem. Phys., 10, 3629-3644, doi:10.5194/acp-10-36292010, 2010.

Ulbrich, I. M., Canagaratna, M. R., Zhang, Q., Worsnop, D. R., and Jimenez, J. L.: Interpretation of organic components from Positive Matrix Factorization of aerosol mass spectrometric data, Atmos. Chem. Phys., 9, 2891-2918, doi:10.5194/acp-9-2891-2009, 2009.

Vardoulakis, S., Fisher, B. E. A., Pericleous, K., and GonzalezFlesca, N.: Modelling air quality in street canyons: a review, Atmos. Environ., 37, 155-182, 2003.

Watson, J. G.: Visibility: Science and regulation, J. Air Waste Manage., 52, 628-713, 2002.
Weimer, S., Mohr, C., Richter, R., Keller, J., Mohr, M., Prévôt, A. S. $\mathrm{H}$., and Baltensperger, U.: Mobile measurements of aerosol number and volume size distributions in an Alpine valley: Influence of traffic versus wood burning, Atmos. Environ., 43, 624-630, 2009.

Xie, S. D., Liu, Z., Chen, T., and Hua, L.: Spatiotemporal variations of ambient $\mathrm{PM}_{10}$ source contributions in Beijing in 2004 using positive matrix factorization, Atmos. Chem. Phys., 8, 27012716, doi:10.5194/acp-8-2701-2008, 2008.

Zavala, M., Herndon, S. C., Wood, E. C., Onasch, T. B., Knighton, W. B., Marr, L. C., Kolb, C. E., and Molina, L. T.: Evaluation of mobile emissions contributions to Mexico City's emissions inventory using on-road and cross-road emission measurements and ambient data, Atmos. Chem. Phys., 9, 6305-6317, doi:10.5194/acp-9-6305-2009, 2009.

Zhang, Q., Stanier, C. O., Canagaratna, M. R., Jayne, J. T., Worsnop, D. R., Pandis, S. N., and Jimenez, J. L.: Insights into the chemistry of new particle formation and growth events in Pittsburgh based on aerosol mass spectrometry, Environ. Sci. Technol., 38, 4797-4809, 2004.

Zhang, Q., Alfarra, M. R., Worsnop, D. R., Allan, J. D., Coe, H., Canagaratna, M. R., and Jimenez, J. L.: Deconvolution and quantification of hydrocarbon-like and oxygenated organic aerosols based on aerosol mass spectrometry, Environ. Sci. Technol., 39, 4938-4952, 2005. 